\title{
Characterizing Monetary and Fiscal Policy Rules and Interactions when Commodity Prices Matter.
}

DOI:

10.1111/manc.12297

\section{Document Version}

Accepted author manuscript

Link to publication record in Manchester Research Explorer

\section{Citation for published version (APA):}

Chuku, C., \& Middleditch, P. (2019). Characterizing Monetary and Fiscal Policy Rules and Interactions when Commodity Prices Matter. The Manchester School, 32. https://doi.org/10.1111/manc.12297

\section{Published in:}

The Manchester School

\section{Citing this paper}

Please note that where the full-text provided on Manchester Research Explorer is the Author Accepted Manuscript or Proof version this may differ from the final Published version. If citing, it is advised that you check and use the publisher's definitive version.

\section{General rights}

Copyright and moral rights for the publications made accessible in the Research Explorer are retained by the authors and/or other copyright owners and it is a condition of accessing publications that users recognise and abide by the legal requirements associated with these rights.

\section{Takedown policy}

If you believe that this document breaches copyright please refer to the University of Manchester's Takedown Procedures [http://man.ac.uk/04Y6Bo] or contact uml.scholarlycommunications@manchester.ac.uk providing relevant details, so we can investigate your claim.

\section{OPEN ACCESS}




\section{Characterizing Monetary and Fiscal Policy Rules and Interactions when Commodity Prices Matter}

\section{Chuku Chuku* and Paul Middleditch**}

**Department of Economics, University of Manchester, Manchester, U.K

*African Development Bank Group, Abidjan, Cote d'Ivoire

Keywords: Economic policy, policy interactions, Markov-switching, Bayesian estimation.

JEL Classification: C51; E52; F41; E62

Email:

*c.chuku@afdb.org,

Corresponding author:**paul.middleditch@manchester.ac.uk 


\begin{abstract}
We examine the extent to which commodity price fluctuations matter for monetary and fiscal policy formulation in high primary commodity export economies. Markov mixture specifications of monetary and fiscal policy rules stylized to account for commodity price slacks are estimated using specifically designed Bayesian techniques. We find that policymakers do indeed respond to commodity price slacks, and with varying degrees, depending on the policy regime in place and the country under investigation. Policy is characterized by distinctive episodes of active and passive policy regimes, driven by the response of monetary policy to inflation and the response of fiscal policy to past government debt. Moreover, monetary authorities fail to act aggressively enough to achieve announced inflation targets or to synchronize with fiscal authorities.
\end{abstract}

Keywords: Economic policy, policy interactions, Markov-switching Bayesian estimation, primary commodities.

JEL Classification: C51; E52; F41; E62

\title{
1 Introduction
}

The great recession of 2008 has reignited the debate surrounding the usefulness of policy tools, and particularly whether policy should be extended to respond to variables such as asset prices, the exchange rate, and other indicators of the business cycle (see for example Bernanke, 2017; Bjrnland and Halvorsen, 2014; Lubik and Schorfheide, 2007; Reinhart and Rogoff, 2009; Siklos and Bohl, 2009; Taylor and Williams, 2010). In spite of this renewed interest, it is possible that economists have overlooked the potential role of commodity prices for monetary and fiscal policy in emerging market economies with significant shares of primary commodities in total export. ${ }^{1}$

\footnotetext{
${ }^{1}$ There are a few exceptions though, some selected studies have recognized the importance of commodity prices in the estimation of monetary policy rules only as a subsidiary variable. For examples, in Bernanke and Gertler $(1999,2001)$ and Clarida et al. (1998).
} 
Recent evidence in this area suggests that commodity prices have certainly been associated with international macroeconomic volatility. Among others, Belke et al. (2014); Caballero et al. (2008), and Hegerty (2016) show that the persistent global imbalances observed in recent decades, the sub-prime crises, asset price bubbles and the debt crises that followed are all interconnected with commodity prices. By careful observation, the connection to commodity prices should not come as a surprise, especially when one considers the global pattern of primary commodity dependence. In 1975, the average share of primary commodities in world merchandise exports was 65.1 percent. In 2015, forty years later, the average share was 48.2 percent, representing a fall of only 25.9 percent over a forty-year period. This indicates that commodity prices, though less dominant, are still an important driving factor in global economic activity.

In this paper, we use an empirical approach to test the importance of commodity price movements for monetary and fiscal policy in selected primary commodity-export economies. We test the validity of the proposition that policy rules in these economies respond to commodity price slacks. Further, we test for episodes of monetary and fiscal policy interactions, to understand if policy rules can be characterized by spells of regime-switching behaviour. Finally, we make statements about the extent of coordination or synchronization between monetary and fiscal policy. We consider a sample of five high primary commodity-export economies, including Brazil, Chile, Mexico, Nigeria, and South Africa. We include Canada in the sample to serve as an industrialized counterpart for benchmarking the results.

But why might commodity prices be an important ingredient for monetary and fiscal policy formulation? Consider three main reasons: first, the so-called Prebisch-Singer hypothesis (Prebisch, 1950; Singer, 1950), which postulates that real commodity prices follow a downward secular trend; second is the long cycles that characterize real commodity prices, which creates booms and busts in income and unemployment; and third, is the time-varying volatility often observed in real commodity prices (see Hadri, 2011; Harvey et al., 2010; Winkelried, 2016; Yamada and Yoon, 2014). If these characteristics are valid, then they hold important implications for monetary and fiscal policy rule specification, budget sustainability rules, and the behaviour of business cycles in high primary commodity export economies.

Our strategy is to modify the standard Taylor's and Leeper's specifications for monetary and fiscal policy reaction functions in such a way that allows us to account for the possibility that high primary commodity export economies need to follow commodity price slacks in formulating 
policies. Further, to accommodate possible endogenous stochastic changes in the characterization of the policy rules, we use simultaneous Markov switching specifications in the parameters and residuals of the model. Our estimation approach uses Bayesian estimation methods with specifically designed Markov chain Monte Carlo (MCMC) based sampling schemes that allow us to avoid the weaknesses of estimating Markov-switching regressions using maximum likelihood techniques. Finally, the equilibrium policy interaction outcomes are evaluated using a framework proposed by Davig and Leeper (2006, 2011).

Overall, we find evidence that policy authorities in all the selected countries react to commodity price slacks but in different ways, depending on the policy regime in place. We also find that policy behaviour in these countries can be characterized by distinctive episodes of active or passive policy regimes, driven by the response of interest rates to inflation, and tax revenues to past government debt. In particular, the monetary authorities in Canada, Chile, Mexico, and South Africa react to commodity price slacks in a counter-cyclical manner by tightening monetary policy, whilst the monetary responses in Brazil and Nigeria seem to be rather pro-cyclical. On the fiscal side, the evidence indicates that only Canada responds to commodity price booms in a countercyclical manner, while the fiscal responses in Brazil, Chile, Nigeria, and South Africa is rather pro-cyclical. Furthermore, we find that the implied inflation targets, when compared with the actual target announced by the respective central banks, indicate that most central banks need to be more aggressive to achieve the announced target. Finally, there is no evidence of policy synchronization between monetary and fiscal policy regime changes in all the selected economies.

The consistent evidence, on the relevance of commodity price slacks and the stochastic regime changing nature of the policy rules estimated, holds at least two interesting implications for the correct specification of macroeconomic models considered suitable for policy analysis in resource-rich export economies. The first is a challenge to the consensus that the Taylor rule, in which monetary policy reacts to inflation, the output gap, and sometimes the exchange rate, has attained a one-size-fits-all status. Our results suggest that, for emerging market economies with structural characteristics leaning towards reliance on primary commodity exports, the inclusion of a commodity price slack component provides a better characterization of policy. Secondly, the regime-switching nature of economic policy reveals the shortcoming in earlier studies on monetary-fiscal policy interactions within New-Keynesian models, in which constant regime specifications are used for both monetary and fiscal policy rules. Our study offers empirical 
support for the recent contributions in the literature with regime-switching specifications of monetary and fiscal policy rules in agent optimization based New-Keynesian models (see for examples, Chung et al., 2007; Davig and Leeper, 2011; Liu et al., 2011).

The rest of this paper is laid out as follows. Section 2 highlights the connection of the paper with the literature on policy reaction functions and their interactions. Section 3 outlines the specification of the monetary and fiscal policy rules used and discusses some issues of identification. Section 4 contains the empirical strategy and the procedure for the implementation of Bayesian simulation-based techniques. Section 5 presents and discusses the results while Section 6 concludes.

\section{Relevant literature}

The seminal papers by Bernanke and Gertler (1999, 2001), and Clarida et al. (1998) were amongst the first to consider the role of primary commodities in monetary policy reaction functions, albeit as auxiliary variables. Specifically, Bernanke and Gertler (1999) investigate whether central banks should respond to asset prices within a simulation and estimation based NK framework, allowing for exogenous bubbles in asset prices, and suggest that deviating from the standard monetary policy tools has the potential to make policy destabilising. The results show that the Fed does not react to changes in stock prices, while the Bank of Japan does. ${ }^{2}$

The literature on monetary and fiscal policy reaction functions for emerging-market economies is sparse in comparison to those that focus on industrialized economies. Nevertheless, some recent studies contain relevant findings. For example, Corbo et al. (2002) find evidence that central banks in Latin American countries tend to consider other non-conventional objectives beyond inflation stabilization when setting interest rates. Mohanty and Klau (2005) use a standard Taylor type open economy reaction function estimated by OLS and GMM techniques to test whether central banks in emerging market economies react to changes in inflation, the output gap and the exchange rate in a consistent and predictable manner. Their results show that in most emerging-market economies, the interest rate responds strongly to the exchange rate and there are asymmetries in the degree of response to both positive and negative inflation shocks.

Empirical studies of policy reaction functions often have to deal with issues of non-

\footnotetext{
${ }^{2}$ In response to this literature, Cecchetti et al. (2000) conduct exploratory experiments on the Bernanke and Gertler (1999) model and show that monetary policy should have and indeed has reacted to asset prices in the U.S.
} 
linearities, structural breaks, and time-varying behaviour. Muscatelli et al. (2002), for example, find evidence of multiple breaks in the estimated policy rules for many countries over a thirty-year period. To account for these kinds of problems, Assenmacher-Wesche (2006) estimate policy rules for selected industrialized countries, using Markov-switching models that allow for shifts in the coefficients as well as residual variance. Similarly, Sims (1999) estimates a three-state Markovswitching model with simultaneous switching in the coefficients and variances to accommodate stochastic endogenous regime changes.

An important strand of the literature on policy rule characterization is the "fiscal theory of the price level (FTPL)", popularized in a series of papers by Woodford (1995, 2001). The FTPL postulates that government debt could serve as an anchor for inflation and economic stabilization. This literature argues that a potentially stabilizing monetary-fiscal policy regime is one that combines a Taylor rule for monetary policy with a nominal deficit targeting rule for fiscal policy. In a related paper, Leeper (1991) examines the equilibrium conditions under which the intertemporal budget constraint is satisfied when there is a shock to real government debt. Can government debt provide a nominal anchor for money? The paper provides analytical conditions for a unique saddle path that pins down the inflation and government debt processes.

In a series of papers, Chung et al. (2007); Davig and Leeper (2006, 2011) explore the implications of monetary and fiscal policy interactions where policy is characterized by spells of stochastic Markov regime changes. The agent's decision rule embeds the probability that policies will change in the future, and this leads to an outcome where monetary and fiscal (tax) shocks produce wealth effects. Drawing from these results, recent empirical studies on simple rules for monetary-fiscal policy interactions have cast the problem in a regime-switching context, estimating the rules by maximum likelihood techniques. For example, Cevik et al. (2014) study the interactions between monetary and fiscal policies in emerging European economies using Markov-switching specifications estimated by maximum likelihood techniques. Their results suggest that monetary and fiscal policy rules in most emerging European economies exhibit switching properties between active and passive policy regimes. ${ }^{3}$

One major concern in the estimation of Markov-regime switching policy rules is the possibility that there are only a few transitions between regimes. This is usually problematic for the accurate estimation of the parameters in the Markov switching model, especially when it is

\footnotetext{
${ }^{3}$ Other examples along these lines include: Chuku (2012); Owyang and Ramey (2004); Semmler and Zhang (2004), and Hutchison et al. (2013)
} 
done by maximum likelihood methods. In addition, there is also the 'curse of dimensionality' problem arising from the explosion in the number of parameters to be estimated in a Markov regime-switching model. We carefully avoid these maximum likelihood-based shortcomings by approaching the estimation of the monetary and fiscal policy rules from a Bayesian technique, with specifically designed sampling techniques (see Fruhwirth-Schnatter, 2004; Kaufmann, 2000; Kim and Nelson, 1999a).

\section{Policy rule specification and identification}

\subsection{The monetary policy rule}

To characterize monetary policy rules in high commodity export economies, we adapt the general class of Taylor-type rules (see Taylor, 1993). According to this rule, 'good' monetary policy involves a systematic reaction by the central bank to deviations of inflation from the set target, and to deviations of output from its potential level. Taylor's baseline characterization of the monetary policy reaction function for the Federal Reserve System is given as

$$
i_{t}^{T}=\bar{r}+\pi^{*}+\alpha_{\pi}\left(\pi_{t}-\pi^{*}\right)+\alpha_{y}\left(y_{t}-y_{t}^{*}\right)
$$

where $i_{t}^{T}$ is the policy interest rate, $\bar{r}$ is the equilibrium real rate, $\pi_{t}$ and $\pi^{*}$ are the inflation rate and its target value respectively, and $\left(y_{t}-y_{t}^{*}\right)$ is the output gap. This formulation has been used to examine central banks' reaction functions across several countries (see Siklos, 2008, for a review). For monetary policy to be stabilizing, the central bank is expected to react according to

the "Taylor principle", where the weight on inflation exceeds unity (i. e. , $\alpha_{\pi}>1$ ), and the weight on the output gap is positive $\left[\alpha_{y} \in(0,1)\right]$.

We consider recent theoretical and empirical refinements of the baseline Taylor rule. First, based on the idea that policymakers conduct monetary policy using future expectations of inflation, we incorporate forward-looking rational expectations in the Taylor rule as in Clarida et al. (1998). Second, we incorporate the exchange rate based on the observation that monetary policy rules augmented with exchange rate movements outperform the conventional rules, especially for small open economies (see Bjrnland and Halvorsen, 2014; Lubik and Schorfheide, 2007; Svensson, 2000). Third, we incorporate interest-rate smoothing behaviour to help account for the fact that 
central banks often follow a gradual mechanism in the adjustment of interest rates in order to avoid abrupt disruptions in the economy (see Goodfriend, 1991; Woodford, 2002). ${ }^{4}$ Finally, we also incorporate commodity price slacks in the baseline Taylor specification thus

$i_{t}=(1-\rho)\left\{\bar{r}+\pi^{*}+\alpha_{\pi}\left(\mathbb{E} \pi_{t+k}-\pi^{*}\right)+\alpha_{y}\left(\mathbb{E} y_{t+p}-y_{t+p}^{*}\right)+\alpha_{c m}\left(\mathbb{E} c_{t+j}-c_{t}^{*}\right)+\alpha_{e x} \Delta e_{t}\right\}$ $+\rho i_{t-i}$

where $\mathbb{E}$ is the expectations operator, $\{c\}$ is a measure of the relevant commodity price sequence, and $\Delta e_{t}$ is the first difference of the exchange rate. Following Clarida et al. (1998), we perform two transformations on Eq. (2): first, we eliminate the unobserved forecast variables by subsuming them into the error term, leaving only observables; second, we collect all constants into one term so that $\alpha_{0}=\bar{r}-\left(\alpha_{\pi}-1\right) \pi^{*}$. The linear version of the estimation equation then becomes

$$
i_{t}=(1-\rho)\left\{\alpha_{0}+\alpha_{\pi} \pi_{t}+\alpha_{y} x_{t}+\alpha_{c m} c_{t}+\alpha_{e x} \Delta e_{t}\right\}+\rho i_{t-i}+\varepsilon_{t},
$$

where $x_{t}$ is the output gap, $c_{t} \equiv \mathbb{E} c_{t+j}-c_{t}^{*}$ is the commodity price slack, and the error term $\varepsilon_{t}$ is defined as a linear combination of the forecast error of inflation, the output gap, and the commodity price slack, thus $\varepsilon_{t} \equiv-(1-\rho)\left[\alpha_{\pi}\left(\pi_{t+k}-\mathbb{E} \pi_{t+k}\right)+\alpha_{y}\left(x_{t+p}-\mathbb{E} x_{t+p}\right)+\right.$ $\left.\alpha_{c m}\left(c_{t+j}-\mathbb{E} c_{t+j}\right)\right]+v_{t}$, where $v_{t}$ is an exogenous disturbance.

To account for non-linearities and possible stochastic regime switching behaviour of the monetary policy reaction function, we specify the Markov-switching version of the model thus

$i_{t}=\left[1-\rho\left(S_{t}^{M}\right)\right]\left\{\alpha_{0}\left(S_{t}^{M}\right)+\alpha_{\pi}\left(S_{t}^{M}\right) \pi_{t}+\alpha_{y}\left(S_{t}^{M}\right) x_{t}+\alpha_{c m}\left(S_{t}^{M}\right) c_{t}+\alpha_{e x}\left(S_{t}^{M}\right) \Delta e_{t}\right\}+$ $\rho i_{t-i}\left(S_{t}^{M}\right)+\varepsilon_{t}\left(S_{t}^{M}\right)$,

where $\left(S_{t}^{M}\right)=1, \ldots, K$ are the unobservable $K$ states of the monetary policy regime, and $\mathbb{P}^{M}$ is the transition probability. In the Markov switching specification, the limiting assumption imposed is that there are two policy regimes: 'active' and 'passive'. There are no restrictions on the sign, magnitude, and timing of the switching coefficients in Eq. 4. Furthermore, as in AssenmacherWesche (2006) and Sims (1999), the error term is also allowed to switch with the coefficients

${ }^{4}$ Other specific reasons why the central bank will not suddenly adjust interest rates to their desired target levels include: the fear of disruption to financial markets (Goodfriend, 1991), to maintain influence over aggregate demand, to mitigate the effects of transaction frictions, and to avoid falling below the interest rate lower bound (see Woodford, 2002). 
between periods of low and high variances, simultaneously. So that

$$
\begin{aligned}
& \varepsilon_{t} \sim N\left(0, \sigma^{2}\left(S_{i}\right)\right) \\
& \sigma^{2}\left(S_{i}\right) \in\left[\sigma_{1}^{2}, \sigma_{2}^{2}\right] ; \quad \sigma_{1}^{2}<\sigma_{2}^{2} .
\end{aligned}
$$

The switching nature of the error term is used to capture idiosyncrasies in the policy implementation process and to capture other non-economic shocks such as the financial crisis and changes in institutional dynamics. An additional advantage of the forward-looking rational expectations approach by Clarida et al. (1998), is that it enables us to back-out the implied inflation target for each monetary policy episode. By assuming that the long-run equilibrium real interest rate $\bar{r}^{*}$ is independent of monetary policy and equal to the ex post average rate, it is possible to back out the implicit inflation target as ${ }^{5}$

$$
\pi^{*}\left(S_{t}^{M}\right)=\frac{\bar{r}^{*}-\alpha_{0}\left(S_{t}^{M}\right)}{\alpha_{\pi}\left(S_{t}^{M}\right)-1}
$$

\subsection{The fiscal policy rule and the policy mix}

Although there are no generally established fiscal policy rules in the literature Leeper (1991) and Bohn (1998)'s specifications are about the most commonly cited. In Leeper's baseline specification, fiscal policy is characterized by government adjusting taxes (or rates) in response to the past values of the real debt. We augment Leeper's rule by including the commodity price slack, output gap, and government expenditure. Further, to account for gradual tax (revenue) smoothing behaviour, we also allow for non-linearities in the form of possible regime changes by introducing an autoregressive term in a first-order Markov-switching specification, so that the estimation equation is given as

$$
\tau_{t}=\gamma_{0}\left(S_{t}^{F}\right)+\gamma_{1}\left(S_{t}^{F}\right) b_{t-1}+\gamma_{2}\left(S_{t}^{F}\right) x_{t}+\gamma_{3}\left(S_{t}^{F}\right) g_{t}+\gamma_{4}\left(S_{t}^{F}\right) c_{t}+\rho\left(S_{t}^{F}\right) \tau_{t-i}+
$$

$\varepsilon\left(S_{t}^{F}\right)$

where $\tau_{t}$ is a measure of the share of (tax) revenue in GDP, $b_{t-1}$ is the lagged value of public debt in GDP, $x_{t}$ is the output gap, $g_{t}$ is government expenditure in GDP, and $c_{t}$ is the commodity price slack.

\footnotetext{
${ }^{5}$ Note that we have defined $\bar{r}^{*}=\bar{r}+\pi^{*}$. The theoretical derivations including justification for this application can be found in Valente (2003) and Favero and Rovelli (2003).
} 
In line with the terminology and characterization Leeper (1991) and Davig and Leeper (2006), fiscal policy is couched 'passive' (or in Woodford (2001)'s terminology Ricardian), if the fiscal authority increases taxes enough to offset interest payments and satisfy the intertemporal budget constraint (IBC) in response to past debt-GDP ratio. For this condition to hold, the estimated coefficient on the lagged debt-GDP ratio is expected to be positive (i.e., $\gamma_{1}>0$ ), so that an increase in the stock of public debt outstanding leads to an increase in tax revenues and hence a decrease in the government budget deficit. Conversely, when $\gamma_{1} \leq 0$, fiscal policy is said to be active and is not constrained by the current budgetary requirements of the fiscal authority. The unobserved state variables in the monetary and fiscal policy rules, $S_{t}^{M}$ and $S_{t}^{F}$, both follow a twostate first-order Markov-switching process described as follows

$$
\begin{array}{ll}
P\left[S_{t}=1 \mid S_{t-1}=1\right]=\xi_{i i}, & P\left[S_{t}=1 \mid S_{t-1}=2\right]=1-\xi_{i i} \\
P\left[S_{t}=2 \mid S_{t-1}=1\right]=1-\xi_{j j}, & P\left[S_{t}=2 \mid S_{t-1}=2\right]=\xi_{j j},
\end{array}
$$

where $\xi$ are the ergodic transition probabilities of remaining in the same state or moving to a different state in the next period. In other words, it is a measure of the persistence of the states. Consequently, the expected duration of the states is a random variable following a geometric distribution with parameter $1-\xi_{j j, i i}$ given by;

$$
\mathbb{E}(D)=\frac{1}{1-\xi_{j j, i i}}
$$

To study monetary-fiscal policy interactions, let $\tilde{\boldsymbol{S}}=\left(S_{t}^{M}, S_{t}^{F}\right)$ denote the joint monetary-fiscal policy states. Then, following Davig and Leeper (2006, 2011), the joint distribution of policy regimes evolves according to a Markov chain with transition matrix $\widetilde{\mathbf{P}}=\mathbb{P}^{M} \otimes \mathbb{P}^{F}$, where $\mathbb{P}^{M}$ and $\mathbb{P}^{F}$ are the transition probability matrices for monetary and fiscal policy regimes respectively. Given the first-order, two-state regime specification for monetary and fiscal policy rules, the joint policy process can be classified into four possible equilibrium outcomes. In Table 1, the equilibrium outcomes for all possible combinations of policy interactions are shown.

Table 1: Equilibrium outcomes of monetary-fiscal policy interactions 


\begin{tabular}{|c|c|c|c|}
\hline & \multicolumn{2}{|c|}{ Monetary Policy } \\
\hline & & Active & Passive \\
\hline \multirow[t]{2}{*}{ Fiscal Policy } & Active & Explosive periods (AF/AM) & FTPL periods (AF/PM) \\
\hline & Passive & Ricardian periods (PF/AM) & Indeterminacy periods (PF/PM) \\
\hline
\end{tabular}

The probabilities on the main diagonal of the inner table represent the outcome for active fiscal and active monetary policy (AF/AM) interaction, and passive fiscal and passive monetary policy (PF/PM) interactions respectively. When both monetary and fiscal policies are active (i.e. AF/AM), then their interaction does not guarantee a sustainable path for the price level and the budget balance - an explosive policy mix. Conversely, when they are both passive (PF/PM), the policy mix is in the region of indeterminacy. The most common specification used in standard DSGE models is the 'active monetary policy-passive fiscal policy' (AM/PF) combination — a Ricardian policy mix. Finally, whenever the price level is determined by the satisfaction of the intertemporal budget constraint, then the policy mix is in the region of the "fiscal theory of the price level (FTPL)", where fiscal policy is active and monetary policy is passive (AF/PM). Our objective is to identify the equilibrium outcomes of policy interaction, and provide a historical description of the joint monetary-fiscal policy episodes for the selected high primary commodity export economies.

\section{Empirical strategy and implementation}

In this section, we describe the approach we have taken; estimating a Markov switching model using Bayesian techniques and also the reasons behind our choice of scope for our analysis, which includes Brazil, Canada, Chile, Mexico, Nigeria and South Africa, from 1990 to 2014.

\subsection{Parameter estimation of the Markov mixture model}

We consider the general form of a Markov switching regression as follows.

$$
y_{t}=X_{t} \beta_{\left(S_{t}\right)}+\varepsilon_{\left(S_{t}\right)}, \quad \varepsilon \sim \mathcal{N}\left(0, \sigma_{\varepsilon,\left(S_{t}\right)}^{2}\right),
$$

where $y^{N}=\left(y_{1}, \ldots, y_{N}\right)$ is the $N \times 1$ vector of the dependent variable, and $X_{t}$ is a vector of explanatory variables, which may also contain lagged dependent variables. The latent variable, $S_{t}$, is the process governing the Markov distribution for which we impose the most flexible 
assumptions. In particular, it is a first-order inhomogeneous Markov chain with the conditional distribution of $S_{t}$ being dependent on the history $\mathbf{y}^{t-1}$ and on its most recent past value $S_{t-1}$. Hence,

$$
\operatorname{Pr}\left(S_{t}=k \mid S^{t-1}, y^{t-1}\right)=\operatorname{Pr}\left(S_{t}=k \mid S_{t-1}, \mathbf{y}^{t-1}\right) ; \quad \forall k \in\{1, \ldots, K\}
$$

The stochastic properties of $S_{t}$ are sufficiently described by the $(K \times K)$ transition matrix $\xi$, where each element $\xi_{j k}$ of $\xi$ represents the transition probabilities of moving from state $j$ (say active) to state $k$ (say passive). That is, $\xi_{j k}=\operatorname{Pr}\left(S_{t}=k \mid S_{t-1}=j\right){ }^{6}$ To define the complete data likelihood function, let $\vartheta=\left(\beta_{S_{t}}, \sigma_{S_{s}}, \xi\right)$ be the collection of all the model parameters and transition probabilities, then the density $p(\mathbf{y}, \mathbf{S} \mid \vartheta)$ of the joint distribution of $\mathbf{S}=\left\{S_{t}\right\}_{0}^{T}$ and $\mathbf{Y}=$ $\left\{Y_{t}\right\}_{0}^{T}$ is given as;

$$
p(\mathbf{y}, \mathbf{S} \mid \vartheta)=p\left(S_{0} \mid \vartheta\right) \prod_{t=1}^{T} p\left(y_{t} \mid \mathbf{y}^{t-1}, \mathbf{S}^{t}, \vartheta\right) p\left(S_{t} \mid \mathbf{S}^{t-1}, \mathbf{y}^{t}, \vartheta\right)
$$

where $p\left(y_{t} \mid \mathbf{y}^{t-1}, \mathbf{S}^{t}, \vartheta\right)=\sqrt{\frac{1}{2 \pi \sigma_{S_{t}}}} \exp \left\{-\frac{\left(y_{t}-X_{t} \beta_{S_{t}}\right)^{2}}{2 \sigma_{S_{t}}}\right\}$ is the Gaussian one-step ahead predictive density of the conditional distribution of $y_{t}$, knowing past realizations of $\mathbf{y}^{t-1}$ and the states $\mathbf{S}^{t}$. While $p\left(S_{t} \mid \mathbf{S}^{t-1}, \mathbf{y}^{t}, \vartheta\right)$ is the density of the conditional distribution of the states $S_{t}$.

Although maximum likelihood (ML) estimation techniques are commonly used to estimate the parameters in Eq. 12 - and especially the expectations-maximization (EM) algorithm by Dempster et al. (1977) (see Kim and Nelson, 1999b) — it suffers from a major weakness in that it is difficult to numerically find the global maximum of the likelihood function, especially when the sample size is small or when the different states are not clearly distinct (see Karlis and Xekalaki, 2003). Secondly, as in any incomplete data problem, the provision of standard errors is not straightforward within an ML estimation procedure, this is partly because of the often nearsingularity of the matrix of second partial derivatives of the log-likelihood. Perhaps the more serious weakness is that ML estimation of Markov mixture models requires very large sample size $N$ before the asymptotic theory of maximum likelihood can apply (see Fruhwirth-Schnatter, 2006,

\footnotetext{
${ }^{6}$ For completeness, it is important to specify the initial distribution of the process. Under strict conditions, one may simply use the ergodic probability distribution. However, with the flexible assumptions used in the paper, it is necessary to use an arbitrary discreet probability distribution, independent of $\xi$. Although, the initial distribution could be treated as an unknown parameter to be estimated from the (see for example Goldfeld and Quandt, 1973), Fruhwirth-Schnatter (2001) suggest the use of the uniform distribution.
} 
p.53). Since large $N$ is not particularly a strength in the samples used for the present study, we consider the more robust alternative of Bayesian estimation using Markov chain Monte Carlo (MCMC) simulations.

To estimate the parameter space, $\vartheta$, using Bayesian techniques, we impose specific informative priors on the parameters and then invoke Bayes theorem, which combines information about $\vartheta$ contained in the complete data likelihood $p(\mathbf{y}, \mathbf{S} \mid \vartheta)$ with the prior information contained in the prior distribution $p(\vartheta)$ to obtain the complete posterior distribution $p(\vartheta \mid \mathbf{y}, \mathbf{S})$ thus;

$$
p(\vartheta \mid \mathbf{y}, \mathbf{S}) \propto p(\mathbf{y}, \mathbf{S} \mid \vartheta) p(\vartheta)
$$

The choice of the prior distribution determines whether or not the posterior distribution is proper or improper. To ensure that the posterior distribution is proper, we choose proper prior densities and assume that the density of the prior distribution is independent of the distribution of the transition probabilities. Thus the prior and posterior distribution are given as

$$
\begin{aligned}
& p(\vartheta)=\prod_{k=1}^{K} p\left(\vartheta_{k}\right) p(\xi), \\
& p(\vartheta \mid \mathbf{y}, \mathbf{S})=\prod_{k=1}^{K} p\left(\boldsymbol{\theta}_{k} \mid \mathbf{y}, \mathbf{S}\right), p(\xi \mid \mathbf{S}),
\end{aligned}
$$

So that the posterior of the complete data Bayesian parameter estimation is the product of the posteriors from the one-step-ahead predictive densities for each state $k=\{1,2\}$,

$$
p\left(\boldsymbol{\theta}_{k} \mid \mathbf{y}, \mathbf{S}\right) \propto \prod_{t: S_{t}=k} p\left(y_{t} \mid \boldsymbol{\theta}_{k}, \mathbf{y}^{t-1}\right) p\left(\boldsymbol{\theta}_{k}\right),
$$

and the posterior of the transition probabilities

$$
p(\xi \mid \mathbf{S}) \propto p\left(S_{0} \mid \xi\right) \prod_{j=1}^{K} \prod_{k=2}^{K} \xi_{j k}^{N_{j k}(\mathbf{S})} p(\xi)
$$

where $N_{j k}(\mathbf{S})=\#\left\{S_{t-1}=j, S_{t}=k\right\}$ counts the number of transitions from state $j$ to $k$.

\subsection{Data}


In this section, we outline the scope of our study and offer the reasons for both the choice of countries and sample periods in our analysis. Whilst we appreciate that the limitations imposed by data availability constraints may affect the results in our study, we propose that these biases are minimised by our choice of estimation technique, one that makes use of informative priors found outside the exact samples that we have utilized. To select countries for the study, we consider an economy in which primary commodities make up more than 60 percent of the total merchandise export as a primary commodity export economy and for this reason include Brazil, Canada, Chile, Mexico, Nigeria and South Africa.

Our data sample is chosen with varying periods, but limited to between 1990 and 2014. This includes Brazil (1998Q1-2014Q4), Canada (1993Q1-2014Q4), Chile (1995Q1-2014Q4), Mexico (1990Q1-2014Q4), Nigeria (1991Q1-2014Q4) and South Africa (1990Q1-2014Q4). Aside from the threshold of primary commodity export, the choice of countries and the time periods are also based on certain characteristics, including clearly separated and defined roles for monetary and fiscal authorities, regional relevance, data availability, and the use of interest ratebased monetary policy rules. Canada is included in the sample as a benchmark for comparison of results between emerging market economies and developed economies. Monetary policy variables - inflation, exchange rate, and the monetary policy rate-are retrieved from the International Financial Statistics (IFS) of the IMF and augmented when necessary with data from the relevant national statistics body.

The commodity price fluctuation is country-specific; it is computed by taking a price index of the major commodities traded by each country. The relevant indices are retrieved from the IMF's primary commodity price tables. ${ }^{7}$ The slack is measured in terms of deviations of the variable from its long-run path in percentage terms. As for the fiscal variables, we have used the updated version of the comprehensive estimates of public debt to GDP ratio computed by Reinhart and Rogoff (2011). Government spending and revenue in GDP are both retrieved from World Development Indicators (WDI), World Bank. The output gap variable is measured by the HPfiltered divergence between actual output and its trend value in percentage terms, scaled by 100 . Further details about the variables used in the empirical exercise and the sources are presented in Table A.1 in the Appendix.

\footnotetext{
7 The country-specific relevant commodities are as follows. For Brazil, iron ore and petroleum; for Chile, copper ore, refined and raw copper; for Canada, crude petroleum, and refined petroleum; for Mexico, crude petroleum; for Nigeria, crude petroleum and petroleum gas; and for South Africa, gold, diamonds, and platinum.
} 


\section{Results and discussion}

In this section, we present the results for our test of the appropriateness of using a non linear Markov switching model over the more traditional linear set up used for estimating monetary and fiscal policy rules. We then present and discuss the results from our estimated monetary and fiscal policy reaction functions that account for movement in commodity prices.

\subsection{Exploratory Bayesian diagnostics}

We start by checking for model specification dominance using the Bayes factor to compare the linear versus Markov switching (non-linear) specifications of the estimated monetary and fiscal policy rules. The results for the marginal log likelihoods and the Bayes factor for the switching versus linear version of the estimated monetary policy rules are presented in Table 2.

Table 2: Linear versus nonlinear specification test for monetary policy rule

\begin{tabular}{|c|c|c|c|}
\hline \multirow[t]{2}{*}{ Country } & \multicolumn{2}{|c|}{ Marginal log likelihood } & \multirow[t]{2}{*}{ Bayes factor } \\
\hline & $\mathcal{M}_{1}$ : Switching & $\mathcal{M}_{2}$ : Linear & \\
\hline \multirow[t]{2}{*}{ Chile } & -120.48 & -131.76 & 11.28 \\
\hline & $(0.003)$ & $(0.002)$ & \\
\hline \multirow[t]{2}{*}{ Mexico } & -266.32 & -349.63 & 83.31 \\
\hline & $(0.008)$ & $(0.001)$ & \\
\hline \multirow[t]{2}{*}{ Nigeria } & $1.44 \mathrm{e}^{03}$ & -218.78 & 218.77 \\
\hline & $(0.008)$ & $(0.001)$ & \\
\hline \multirow[t]{2}{*}{ Brazil } & -134.22 & -137.71 & 3.49 \\
\hline & $(0.004)$ & $(0.002)$ & \\
\hline \multirow[t]{2}{*}{ South Africa } & -140.79 & -153.91 & 13.12 \\
\hline & $(0.003)$ & $(0.001)$ & \\
\hline \multirow[t]{2}{*}{ Canada } & -86.75 & -88.26 & 1.51 \\
\hline & $(0.005)$ & $(0.001)$ & \\
\hline
\end{tabular}

The results clearly show that the non-linear switching specification dominates the linear specification for all the countries, although the strength of the evidence in favour of the switching regression varies by country. For Chile, Mexico, Nigeria, and South Africa the evidence is strong; 
whereas for Brazil and Canada, the evidence is relatively weak. Thus, we proceed with the discussion of the results for the Markov switching specification.

Figure 1: Point process representation for matrix of parameters
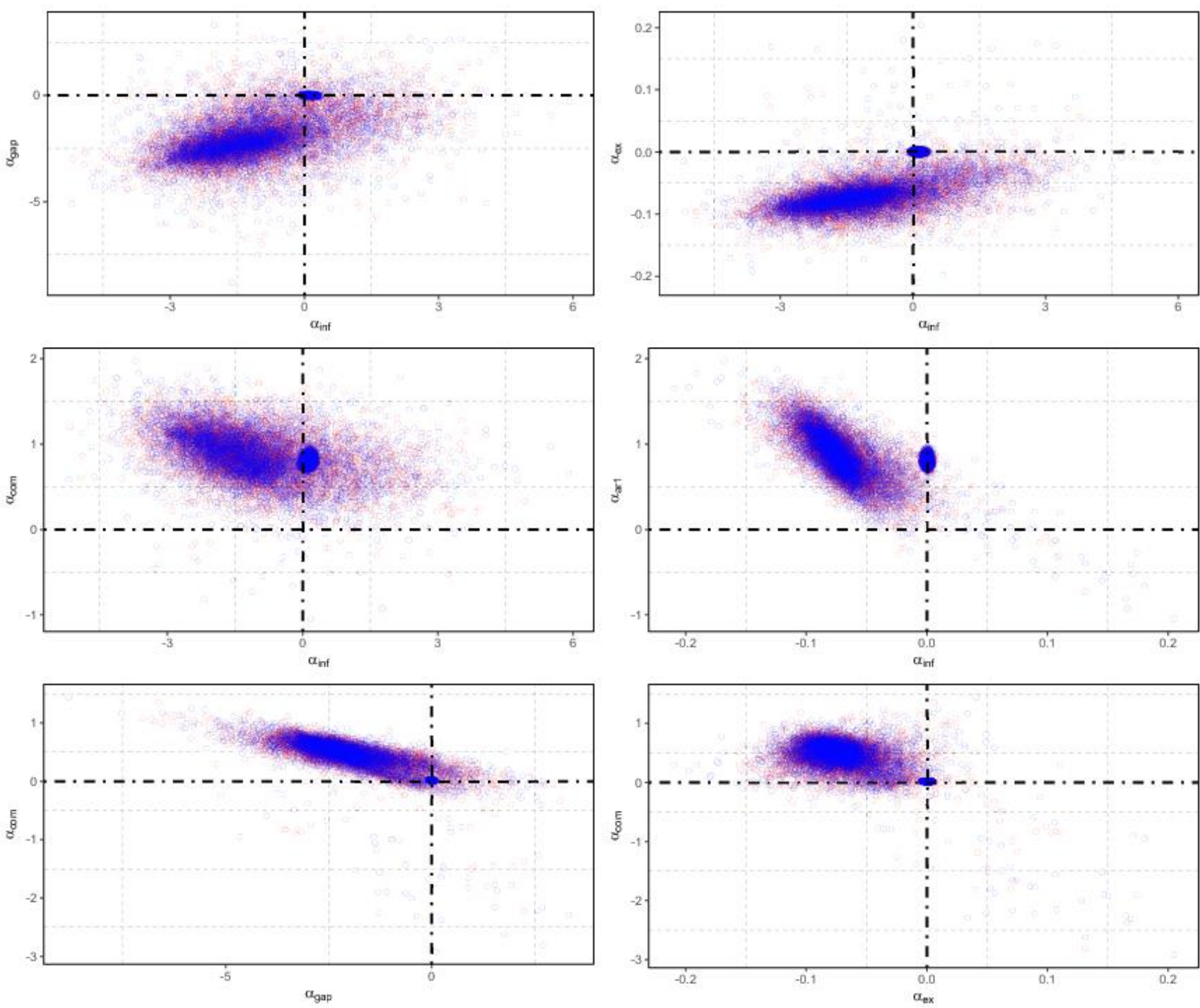

Further, we conduct identification checks for the correct number of policy states in the model by visualizing the scatter plots of the point process representation of the MCMC draws for the parameters. This process helps us to answer questions about whether the model is over-fitting in the number of states or not, without worrying about problems of label switching (see Kaufmann, 2002, for example). In Fig. 1, we plot the point process representation of the parameters for Chile, 
which is qualitatively the typical pattern we observe across the selected countries. To interpret the charts in Figure 1, it is important to note that the MCMC draws are expected to scatter around the points corresponding to the true point process representation of the states, with the spread of the clouds representing the uncertainty of estimating the points. Moreover, the number of clusters visible in the plot provides indicative insights on the number of states present in the system, and the parameters driving the switching process. If the marginal densities cluster around zero for all the states, this can be interpreted as an indication that the model is over-fitted, and the order of the model needs to be reduced. But if the simulation clusters are shifted away from zero, then it is interpreted as providing no explanatory evidence to reduce the model order further (see Fruhwirth-Schnatter, 2006:367 for more guidance on how to interpret the Bayesian exploratory analysis using the point process representation plots)

The first four panels in Figure 1 show that the parameter for inflation is the primary driver of the switching behaviour. This finding provides further empirical support to Leeper (1991)'s classification of policy stance based on the reaction of policy to inflation. In addition, since at least two clusters are discernible from the panels in Figure 1, it implies that the model does not suffer from problems of under-fitting of the states. The spread of the clusters, however, suggest modest degrees of uncertainty and wider confidence intervals for some parameter estimates. Other figures used to monitor the convergence, stability, and identifiability of the Bayesian estimates are available upon request from the authors.

\subsection{Do monetary and fiscal authorities respond to commodity price slacks?}

To answer the question of whether or not, and to what extent monetary and fiscal authorities in resource export economies respond to commodity price slacks, we formally test the hypothesis: $\mathcal{M}_{1}: \alpha_{c m} \neq 0$ against the alternative $\mathcal{M}_{2}: \alpha_{c m}=0$, using the marginal log likelihoods and Bayes factor for each reaction function. The results of the formal test of the relevance of commodity price slacks in the monetary policy rule are presented in Table 3. The results indicate that there is substantial evidence that the monetary authorities in Brazil, Canada, Mexico and South Africa react to commodity price slacks in the monetary policy rule, with the Bayes factor in favour of the model with the commodity price slack ranging between 7.76 and 5.17. The evidence is, however, weak for Chile with a Bayes factor of 0.56 and outrightly rejected for Nigeria with a negative Bayes factor. 
Table 3: Specification test for commodity slack in the monetary policy rule.

\begin{tabular}{llll}
\hline Country & \multicolumn{2}{l}{ Marginal log likelihood } & Bayes factor \\
\hline & $\mathcal{M}_{1}: \alpha_{c m} \neq 0$ & $\mathcal{M}_{1}: \alpha_{c m}=0$ & \\
\hline Chile & -120.48 & -121.04 & 0.56 \\
& $(0.003)$ & $(0.004)$ & 7.25 \\
Mexico & -266.32 & -273.57 & \\
& $(0.008)$ & $(0.004)$ & $-5.12 \mathrm{e}^{-05}$ \\
Nigeria & $1.44 \mathrm{e}^{03}$ & $1.49 \mathrm{e}^{03}$ & \\
& $(0.008)$ & $(0.009)$ & 6.51 \\
Brazil & -134.22 & -140.73 & 5.17 \\
& $(0.004)$ & $(0.004)$ & \\
South Africa & -140.79 & -145.96 & 7.76 \\
& $(0.003)$ & $(0.003)$ & \\
Canada & -86.75 & -94.51 & $(0.005)$ \\
& $(0.005)$ & 5 &
\end{tabular}

Standard errors are in parenthesis. Results are based on 12,000 simulations with a burn-in of 2000 draws. Bayes factor is the ratio of the Marginal log likelihood.

The results of the test of the relevance of commodity price slacks in the fiscal policy rule are presented in Table 4. Similarly, we test the hypothesis: $\mathcal{M}_{1}: \gamma_{c m} \neq 0$ against the alternative that $\mathcal{M}_{2}: \gamma_{c m}=0$ for each country. Overall, the Bayes factor indicates strong evidence in favour of the proposition that $\mathcal{M}_{1}: \gamma_{c m} \neq 0$. In particular, the Bayes factor for Brazil is 3.81, for Nigeria 14.65 and for South Africa 5.68. The evidence for Canada is weak, with a Bayes factor of 2.06. Conversely, for Mexico, the hypothesis is outrightly rejected.

Table 4: Specification test for commodity slack in the fiscal policy rule

\begin{tabular}{|c|c|c|c|}
\hline \multirow[t]{2}{*}{ Country } & \multicolumn{2}{|c|}{ Marginal log likelihood } & \multirow[t]{2}{*}{ Bayes factor } \\
\hline & $\mathcal{M}_{1}: \gamma_{c m} \neq 0$ & $\mathcal{M}_{2}: \gamma_{c m}=0$ & \\
\hline Chile & $\begin{array}{l}-44.98 \\
(0.005)\end{array}$ & $\begin{array}{l}-55.92 \\
(0.004)\end{array}$ & 10.94 \\
\hline Mexico & $\begin{array}{l}1.47 \mathrm{e}^{03} \\
(0.001)\end{array}$ & $\begin{array}{l}1.51 \mathrm{e}^{03} \\
(0.015)\end{array}$ & $-4.11 e^{-05}$ \\
\hline Nigeria & $\begin{array}{l}-218.07 \\
(0.007)\end{array}$ & $\begin{array}{l}-232.72 \\
(0.004)\end{array}$ & 14.65 \\
\hline
\end{tabular}




\begin{tabular}{llll} 
Brazil & -49.10 & -52.91 & 3.81 \\
& $(0.002)$ & $(0.004)$ & 5.68 \\
South Africa & -38.61 & -44.29 & 2.06 \\
& $(0.007)$ & $(0.007)$ & \\
Canada & 7.69 & 5.63 \\
\multicolumn{2}{r}{ Standard errors are in parenthesis. Results are based on 12,000 simulations with a burn-in of 2000 draws. Bayes factor is the ratio } \\
& of the Marginal log likelihood.
\end{tabular}

\subsection{The monetary policy reaction function}

The results from the estimation of the Markov-switching monetary policy rules are in Table 5. We define the nomenclature in the table. The ergodic means are computed from the posterior distribution of the parameters after identification using, following unconstrained permutation sampling from 10,000 iterations with a burn-in phase of 2,000 iterations. The 95 percent credible set contains the 95 percent highest posterior density interval (HPDI) for the estimated parameters. $\pi^{\mathrm{a}}$ is the implied inflation target, $\mathbb{P}_{i i}$ is the persistence probability, or the probability of remaining in the same state when moving from periods 1 to $2, \mathbb{P}_{i j}$ is the transition probability, and $\mathbb{E}(D)$ is the expected duration of the policy rule. The results show that, apart from Brazil, there is a clear distinction between the "active" and "passive" monetary policy regimes for Canada, Chile, Mexico, Nigeria, and South Africa. The classification of the policy regime follows Davig and Leeper (2006, 2011)'s characterization. That is, estimates of the inflation parameter, which satisfy the Taylor principle $\alpha_{\pi}>1$, are interpreted as active monetary policy regimes, whereas values that are less than one are interpreted as passive monetary policy regimes. 
Table 5: Bayesian estimates for regime-switching monetary policy rule

\begin{tabular}{|c|c|c|c|c|c|c|c|c|}
\hline & \multicolumn{4}{|c|}{ Chile } & \multicolumn{4}{|c|}{ Mexico } \\
\hline & \multicolumn{2}{|c|}{ Active policy } & \multicolumn{2}{|c|}{ Passive policy } & \multicolumn{2}{|c|}{ Active policy } & \multicolumn{2}{|c|}{ Passive policy } \\
\hline & $\begin{array}{l}\text { Ergodic } \\
\text { mean }\end{array}$ & $\begin{array}{c}95 \% \text { Credible } \\
\text { set }\end{array}$ & $\begin{array}{l}\text { Ergodic } \\
\text { mean }\end{array}$ & $95 \%$ Credible set & $\begin{array}{c}\text { Ergodic } \\
\text { mean }\end{array}$ & $\begin{array}{c}95 \% \text { Credible } \\
\text { set }\end{array}$ & $\begin{array}{c}\text { Ergodic } \\
\text { mean }\end{array}$ & $\begin{array}{l}95 \% \text { Credible } \\
\text { set }\end{array}$ \\
\hline$\alpha_{0}\left(s_{t}^{M}\right)$ & $\begin{array}{l}12.347 \\
(0.984)\end{array}$ & $\begin{array}{r}10.269 \\
14.205]\end{array}$ & $\begin{array}{r}0.802 \\
(0.184)\end{array}$ & {$[0.566,1.038]$} & $\begin{array}{r}12.56 \\
(0.015)\end{array}$ & {$[12.531,12.59]$} & $\begin{array}{r}12.56 \\
(0.014)\end{array}$ & {$[12.54,12.58]$} \\
\hline$\alpha_{\pi}\left(s_{t}^{M}\right)$ & $\begin{array}{l}2.935 \\
(0.41)\end{array}$ & {$[2.115,3.75]$} & $\begin{array}{r}0.118 \\
(0.054)\end{array}$ & {$[0.01,0.226]$} & $\begin{array}{r}1.471 \\
(0.104)\end{array}$ & {$[1.261,1.680]$} & $\begin{array}{r}0.012 \\
(0.103)\end{array}$ & {$[-0.194,0.221]$} \\
\hline$\alpha_{y}\left(s_{t}^{M}\right)$ & $\begin{array}{r}0.515 \\
(0.085)\end{array}$ & {$[0.345,0.683]$} & $\begin{array}{r}0.008 \\
(0.026)\end{array}$ & {$[-0.044,0.06]$} & $\begin{array}{r}1.013 \\
(0.082)\end{array}$ & {$[0.849,1.177]$} & $\begin{array}{r}-0.004 \\
(0.081)\end{array}$ & {$[-0.167,0.159]$} \\
\hline$\alpha_{e x}\left(s_{t}^{M}\right)$ & $\begin{array}{l}-0.028 \\
(0.005)\end{array}$ & $\begin{array}{r}{[-0.038,-} \\
0.018]\end{array}$ & $\begin{array}{r}0.002 \\
(0.001)\end{array}$ & {$[0,0.004]$} & $\begin{array}{r}2.464 \\
(0.149)\end{array}$ & {$[2.165,2.762]$} & $\begin{array}{r}0.055 \\
(0.147)\end{array}$ & {$[-0.239,0.351]$} \\
\hline$\alpha_{c m}\left(s_{t}^{M}\right)$ & $\begin{array}{r}1.198 \\
(0.025)\end{array}$ & {$[1.188,1.208]$} & $\begin{array}{r}0.018 \\
(0.004)\end{array}$ & {$[0.01,0.026]$} & $\begin{array}{r}0.144 \\
(0.021)\end{array}$ & {$[0.101,0.187]$} & $\begin{array}{l}-0.002 \\
(0.021)\end{array}$ & {$[-0.045,0.041]$,} \\
\hline$\rho_{1}\left(s_{t}^{M}\right)$ & $\begin{array}{l}-0.445 \\
(0.123)\end{array}$ & $\begin{array}{r}{[-0.691,-} \\
0.199]\end{array}$ & $\begin{array}{r}0.827 \\
(0.038)\end{array}$ & {$[0.751,0.903]$} & $\begin{array}{r}0.753 \\
(0.015)\end{array}$ & {$[0.723,0.784]$} & $\begin{array}{r}0.851 \\
(0.014)\end{array}$ & {$[0.822,0.881]$} \\
\hline$\sigma\left(s_{t}^{M}\right)$ & 0.51 & & 0.45 & & 7.41 & & 1.33 & \\
\hline $\mathbb{P}_{i i}$ & 0.95 & & 0.69 & & 0.72 & & 0.93 & \\
\hline $\mathbb{P}_{i j}$ & 0.05 & & 0.31 & & 0.28 & & 0.07 & \\
\hline $\mathbb{E}(D)$ & 20 & & 3.22 & & 3.57 & & 14.2 & \\
\hline$\pi^{*}$ & 3.92 & & 8.61 & & 8.19 & & & \\
\hline MixLik & -70.77 & & & & -224.49 & & & \\
\hline
\end{tabular}




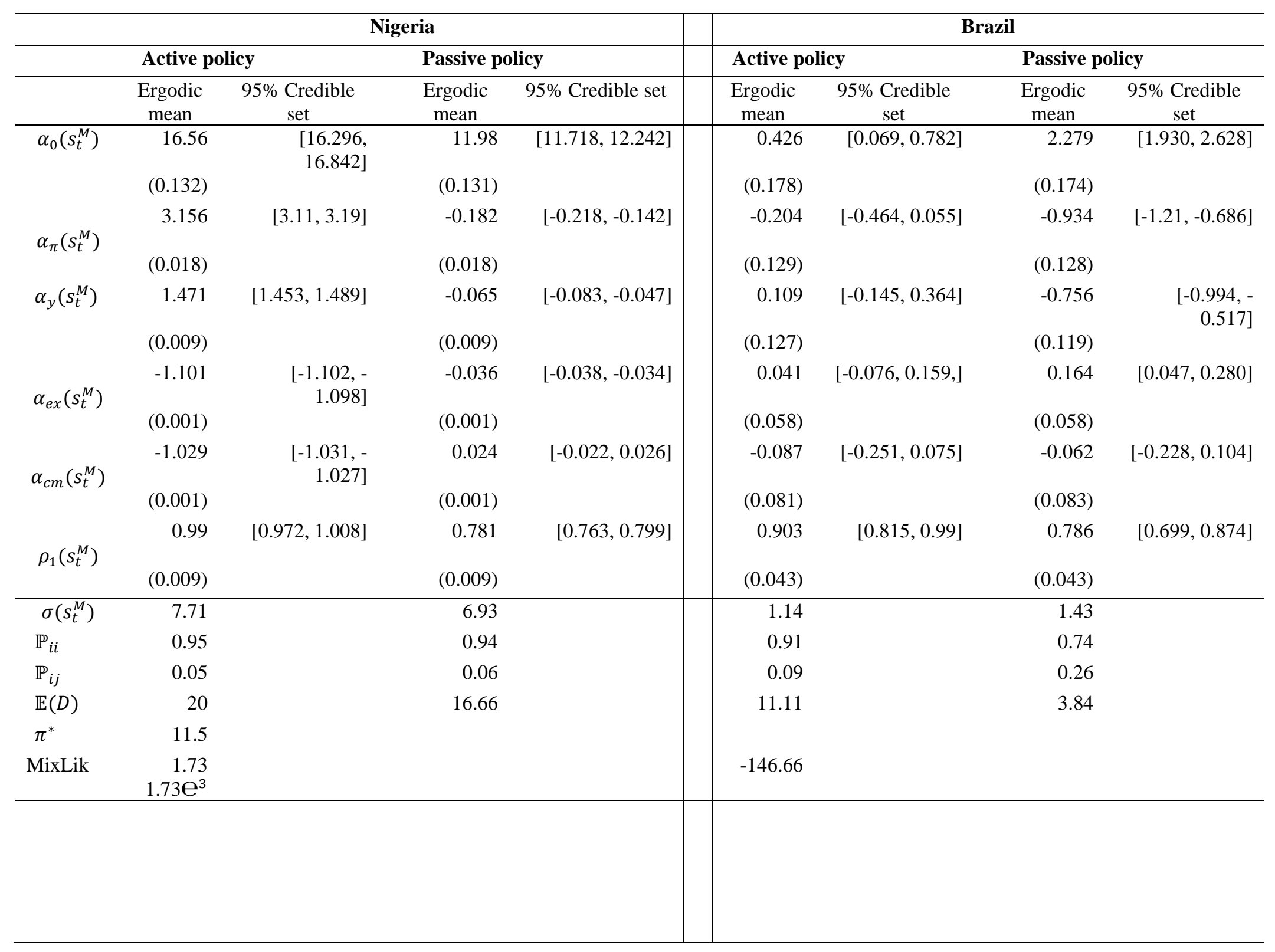




\begin{tabular}{|c|c|c|c|c|c|c|c|c|}
\hline & \multicolumn{4}{|c|}{ South Africa } & \multicolumn{4}{|c|}{ Canada } \\
\hline & \multicolumn{2}{|c|}{ Active policy } & \multicolumn{2}{|c|}{ Passive policy } & \multicolumn{2}{|c|}{ Active policy } & \multicolumn{2}{|c|}{ Passive policy } \\
\hline & $\begin{array}{l}\text { Ergodic } \\
\text { mean }\end{array}$ & $\begin{array}{c}95 \% \text { Credible } \\
\text { set }\end{array}$ & $\begin{array}{l}\text { Ergodic } \\
\text { mean }\end{array}$ & 95\% Credible set & $\begin{array}{c}\text { Ergodic } \\
\text { mean }\end{array}$ & $\begin{array}{c}95 \% \text { Credible } \\
\text { set }\end{array}$ & $\begin{array}{l}\text { Ergodic } \\
\text { mean }\end{array}$ & $\begin{array}{c}95 \% \text { Credible } \\
\text { set } \\
\end{array}$ \\
\hline$\alpha_{0}\left(s_{t}^{M}\right)$ & $\begin{array}{r}21.785 \\
(0.151)\end{array}$ & $\begin{array}{r}21.483, \\
22.087]\end{array}$ & $\begin{array}{r}0.168 \\
(0.143)\end{array}$ & {$[0.566,1.038]$} & $\begin{array}{r}2.525 \\
(0.151)\end{array}$ & {$[2.223,2.827]$} & $\begin{array}{r}1.309 \\
(0.143)\end{array}$ & {$[0.566,1.038]$} \\
\hline$\alpha_{\pi}\left(s_{t}^{M}\right)$ & $\begin{array}{r}2.502 \\
(0.127)\end{array}$ & {$[2.246,2.758]$} & $\begin{array}{r}0.045 \\
(0.131)\end{array}$ & {$[-0.216,0.306]$} & $\begin{array}{r}1.233 \\
(0.097)\end{array}$ & {$[1.038,1.427]$} & $\begin{array}{l}-0.079 \\
(0.099)\end{array}$ & {$[-0.275,0.123]$} \\
\hline$\alpha_{y}\left(s_{t}^{M}\right)$ & $\begin{array}{r}0.951 \\
(0.109)\end{array}$ & {$[0.733,1.169]$} & $\begin{array}{r}0.206 \\
(0.108)\end{array}$ & {$[-0.009,0.422]$} & $\begin{array}{r}0.028 \\
(0.051)\end{array}$ & {$[-0.074,0.133]$} & $\begin{array}{r}0.199 \\
(0.049)\end{array}$ & {$[-0.099,0.295]$} \\
\hline$\alpha_{e x}\left(s_{t}^{M}\right)$ & $\begin{array}{r}0.611 \\
(0.138)\end{array}$ & {$[0.335,0.887]$} & $\begin{array}{r}0.011 \\
(0.142)\end{array}$ & {$[-0.271,0.294]$} & $\begin{array}{r}1.807 \\
(0.164)\end{array}$ & {$[2.134,1.479]$} & $\begin{array}{r}0.712 \\
(0.163)\end{array}$ & {$[0.424,1.079]$} \\
\hline$\alpha_{c m}\left(s_{t}^{M}\right)$ & $\begin{array}{r}1.21 \\
(0.093)\end{array}$ & {$[1.023,1.396]$} & $\begin{array}{r}0.005 \\
(0.094)\end{array}$ & {$[-0.183,0.194]$} & $\begin{array}{r}0.078 \\
(0.008)\end{array}$ & {$[0.062,0.094]$} & $\begin{array}{l}-0.005 \\
(0.008)\end{array}$ & {$[-0.021,0.011]$} \\
\hline$\rho_{1}\left(s_{t}^{M}\right)$ & $\begin{array}{r}0.315 \\
(0.037)\end{array}$ & {$[0.2399,0.391]$} & $\begin{array}{r}0.908 \\
(0.038)\end{array}$ & {$[0.831,0.985]$} & $\begin{array}{l}0.588 \\
(0.03)\end{array}$ & {$[0.529,0.649]$} & $\begin{array}{r}0.715 \\
(0.028)\end{array}$ & {$[0.659,0.75]$} \\
\hline$\sigma\left(s_{t}^{M}\right)$ & 0.93 & & 0.48 & & 0.62 & & 0.32 & \\
\hline $\mathbb{P}_{i i}$ & 0.76 & & 0.97 & & 0.68 & & 0.95 & \\
\hline $\mathbb{P}_{i j}$ & 0.24 & & 0.03 & & 0.32 & & 0.05 & \\
\hline $\mathbb{E}(D)$ & 4.16 & & 33.3 & & 3.12 & & 20 & \\
\hline$\pi^{*}$ & 8.74 & & & & 2.52 & & & \\
\hline MixLik & -103.59 & & & & -41.01 & & & \\
\hline
\end{tabular}

The ergodic means are estimates of the averages from the posterior distribution after identification using unconstrained permutation sampling of 10,000 iterations with a burn-in phase of 2,000 iterations. The 95\% credible set contains the $95 \%$ highest posterior density interval (HPDI) for the estimated parameters. Standard errors are in parenthesis. $\pi^{\mathfrak{a}}$ is the implied inflation, $\mathbb{P}_{i i}$ is the persistence probability, ie. the probability of remaining in the same state from periods 1 to $2 . \mathbb{P}_{i j}$ is the transition probability, and $\mathbb{E}(D)$ is the expected duration of the policy rule. 
Furthermore, the results show that during active monetary policy regimes, the reaction of interest rates to inflation ranges between 1.23 and 3.15. These estimates are within close range when compared to recent results in the literature. For example, in a constant regime, Bayesian IV estimation of the policy rule for Canada, Lubik and Schorfheide (2007) obtain a value of 1.51, which is close when compared to the value of 1.23 we obtain on the inflation coefficient in the active regime. Similarly, for Chile, we get a coefficient of 2.93 and 0.11; Mexico, 1.47 and 0.01; Nigeria, 3.15 and -0.18; and South Africa, 2.51 and 0.04 for the active and passive monetary policy regimes, respectively.

These results are somewhere in between single regime policy rules estimated for these economies by Mohanty and Klau (2005). ${ }^{8}$ We obtain the implied inflation target for each economy in the sample by plugging in the inflation coefficients during the active monetary policy regime into Eq. 6. The implied inflation target, when compared with the actual target announced by the respective central banks, indicates that most central bank's reaction to inflation is often not "hawkish" (aggressive) enough to achieve the announced target. For example, during the period under investigation, Chile and Mexico announced an inflation target of 3 percent, but the results indicate that their responses to inflation imply an inflation target of about 4 percent and 8.1 percent respectively. Canada announced an inflation target of 2 percent, the rule implies 2.52 percent. Nigeria and South Africa announced targets of between 6 to 9 percent and 3 to 6 percent respectively, but the estimated policy rules suggest they are pursuing an inflation target of around 11.5 and 8.7 percent respectively.

In so far as output stabilization is concerned, the evidence is mixed. In most cases, the sign of the coefficient on the output gap is positive, especially in the active policy regime. During passive monetary regimes, the phenomenon noted by Owyang and Ramey (2004), where output stabilization receives greater weights relative to inflation stabilization, does not seem to hold in these economies, except for Canada. Here we caution that the estimates for the output gap should be interpreted with care, the reason is that they are likely to suffer from a downward bias due to the greater difficulty of measuring the output gap for emerging-market economies compared to industrialized economies. Another potential reason for the mixed evidence on output stabilization could be the role of other macroeconomic policies, especially fiscal policy in output stabilization for emerging market economies (see Sidaoui, 2003, for the experience in Mexico).

\footnotetext{
${ }^{8}$ Mohanty and Klauy find the following inflation coefficients: Chile 0.97, Mexico 0.55, and South Africa 0.08.
} 
In all the countries, except for Chile and Nigeria, the exchange rate variable uniformly returns positive average coefficients, suggesting that monetary authorities 'lean against the wind' by tightening monetary policy in response to nominal exchange rate depreciation and vice versa, with the degree of tightening depending on the current state of the policy regime-active or passive. In particular, the range of the coefficient is between 2.46 percent (during active policy regimes in Mexico), and 0.01 percent (during passive policy regimes in South Africa). Our results are slightly higher than the single regime estimates by Mohanty and Klau (2005) for emergingmarket economies and generally lower than the Bayesian IV estimates by Lubik and Schorfheide (2007) for Canada, but loosely comparable to the GMM estimates by Clarida et al. (1998) for industrialized economies. Moreover, the results show that there is a high degree of interest rate smoothing by the central banks, this is inferred from the average estimate of the autoregressive parameters which is somewhere around 0.65 , depending on the prevailing policy regime.

While we find evidence that the monetary authorities in these primary commodity export economies respond to commodity price slacks, there is considerable variation, by country, in the nature of the responses and this often depends on whether policy is in the active or passive regime. In particular, the results show that during active monetary policy regimes, Canada, Chile, Mexico, and South Africa respond to commodity price booms in a counter-cyclical manner by tightening monetary policy. This is, however, not the case for Brazil and Nigeria where monetary policy seems to be pro-cyclical in response to commodity price booms, thereby accentuating the effects of commodity price fluctuations on the domestic economy.

This observed policy stance by central banks in resource export economies, where they simultaneous target both the headline inflation and the relevant commodity price index is akin to the product price targeting (PPT) scheme that Frankel (2011) proposed as the optimal strategy for primary commodity export economies. It is important to note that Canada has been following what may be considered an equivalent strategy, whereby policy responds to a monetary conditions index (MCI) that includes domestic prices, the exchange rate, and some index of commodity prices (see Lubik and Schorfheide, 2007). 
Figure 2: Filtered and smoothed transition probabilities for active monetary policy
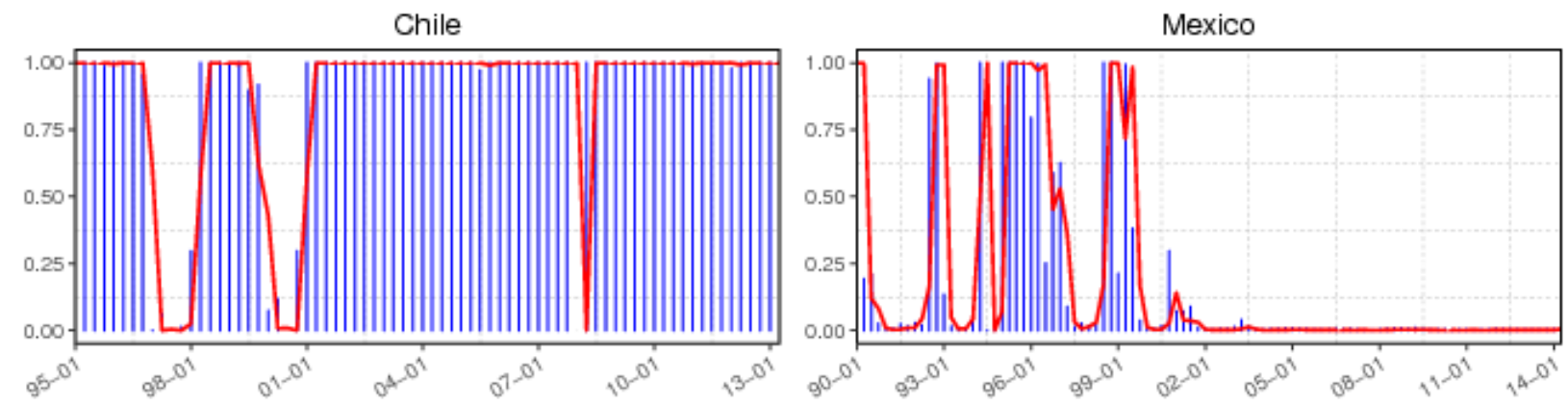

Nigeria
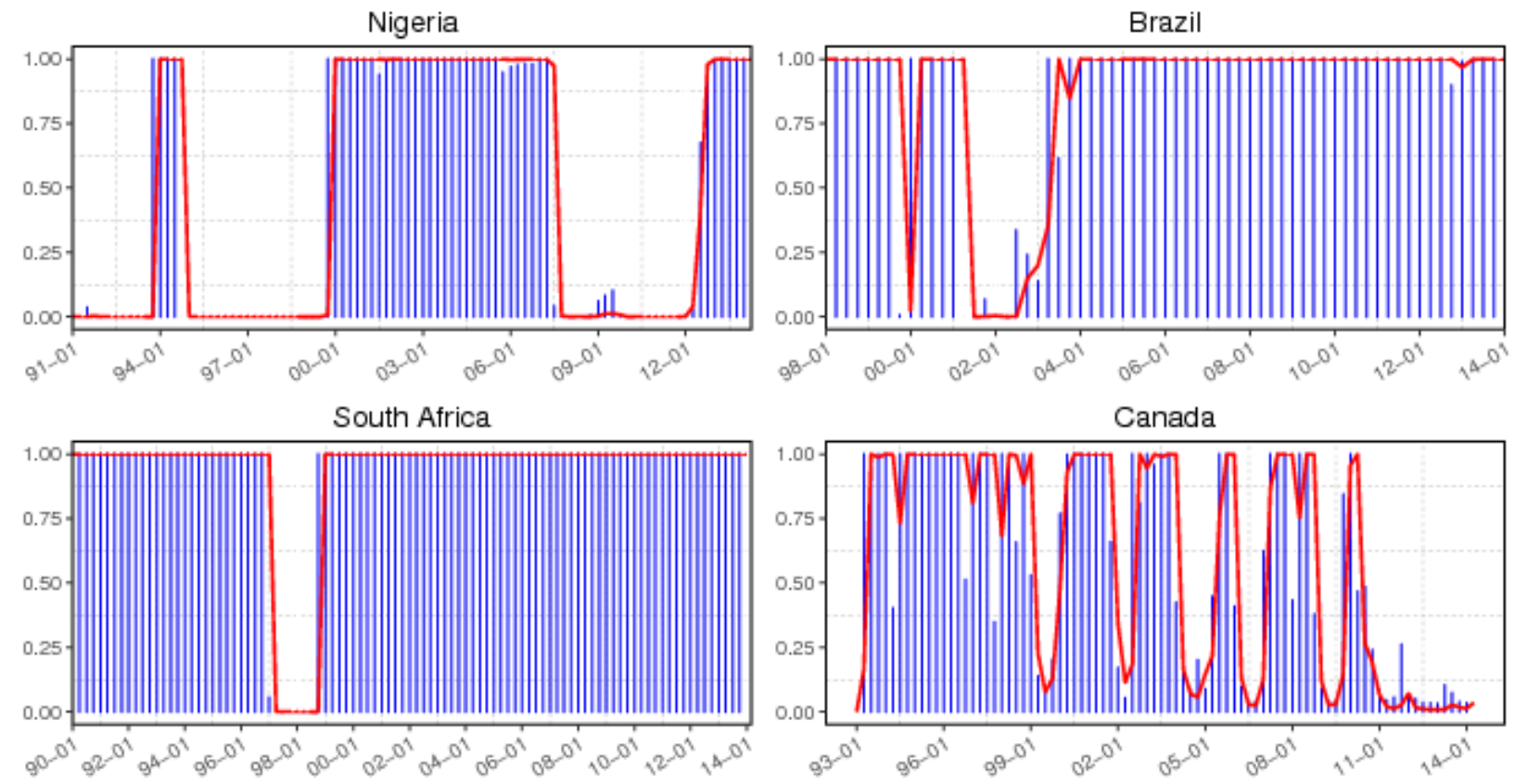

The stationary transition probabilities for the active policy regime $\mathbb{P}_{i i}$ ranges between 0.95 in Nigeria and 0.68 in Canada, and for the passive regime $\mathbb{P}_{j j}$, it ranges between 0.97 in South Africa and 0.74 in Brazil. This high degrees of persistence for most countries show that once policy is in a certain regime, the likelihood of remaining in the same regime the next period is very high. In particular, the results imply that the average expected duration $\mathbb{E}(D)$ of remaining in the active policy episode is around 8 quarters ( 2 years), and the expected duration for remaining in a passive policy episode, is around 4 quarters ( 1 year).

The filtered (plotted as bars) and smoothed (plotted as lines) transition probabilities of being in the active monetary policy regime are depicted in Figure $2 .{ }^{9}$ This plot helps to answer

${ }^{9}$ Note, that the chart in Figure 2 shows transition probabilities for policy reaction functions, we did not try to identify recessions and booms or business cycles, so in this case we cannot match these probabilities with episodes in respective business cycles. 
questions about whether the periods estimated to be active and passive correspond with the narrative and observed accounts of policy history in these economies. From the pattern of the transition probabilities in Figure 2, three cases seem to stand out: Brazil, Chile, and South Africa. For these countries, apart from the short spells of passive monetary policy regimes in the early 2000s, monetary policy has mostly been active since 2004 and beyond.

\subsection{The fiscal policy reaction function}

For the fiscal policy reaction function, we begin by discussing the results of the test of specification dominance between the linear and Markov switching (non-linear) specifications. The marginal log likelihoods and Bayes factor for both specifications of the fiscal policy rule are contained in Table 6.

Table 6: Linear versus nonlinear specification test for fiscal policy rule

\begin{tabular}{llll}
\hline \multicolumn{1}{c}{ Country } & \multicolumn{2}{c}{ Marginal log likelihood } & Bayes factor \\
\hline & $\mathcal{M}_{1}:$ Switching & $\mathcal{M}_{2}:$ Linear & \\
\hline Chile & -44.98 & -67.03 & 22.05 \\
& $(0.005)$ & $(0.002)$ & 105.99 \\
Mexico & $1.47 \mathrm{e}^{03}$ & -105.99 & \\
& $(0.001)$ & $(0.001)$ & 0.51 \\
Nigeria & -218.07 & -218.58 & -2.27 \\
& $(0.007)$ & $(0.001)$ & \\
Brazil & -49.10 & -46.83 & 37.86 \\
& $(0.002)$ & $(0.002)$ & 7.41 \\
South Africa & -38.61 & -76.47 & \\
& $(0.007)$ & $(0.001)$ & \\
Canada & 7.69 & 0.28 & \\
& $(0.006)$ & $(0.001)$ & \\
\hline
\end{tabular}

Standard errors are in parenthesis. Results are based on 12,000 simulations with a burn-in of 2000 draws. Bayes factor is the ratio of the Marginal log likelihood.

With the exception of Brazil, the Bayes factor indicates that the non-linear Markov switching specification of the fiscal policy rule is the more probable of the two models considered. The evidence in favour of the non-linear specification is decisive for Mexico; strong for Canada, Chile, and South Africa; weak for Nigeria; and outrightly rejected for Brazil. There are several possible reasons for the rejection of the nonlinear model for Brazil, one could be because of the sample size, which lies between 1998Q1 and 2014Q4, relatively shorter than the sample size for other 
countries in the region. Another reason, as we will see later in the results for policy interactions, is that fiscal policy was mainly active between the relatively short period of 2001 and 2003 for Brazil and yet for the wider sample, policy interactions have been explosive (see Figure 4). 
Table 7: Bayesian estimates for regime-switching fiscal policy rule

\begin{tabular}{|c|c|c|c|c|c|c|c|c|}
\hline & \multicolumn{4}{|c|}{ Chile } & \multicolumn{4}{|c|}{ Mexico } \\
\hline & \multicolumn{2}{|c|}{ Active policy } & \multicolumn{2}{|c|}{ Passive policy } & \multicolumn{2}{|c|}{ Active policy } & \multicolumn{2}{|c|}{ Passive policy } \\
\hline & $\begin{array}{c}\text { Ergodic } \\
\text { mean }\end{array}$ & $\begin{array}{c}95 \% \text { Credible } \\
\text { set }\end{array}$ & $\begin{array}{c}\text { Ergodic } \\
\text { mean }\end{array}$ & $\begin{array}{l}\text { 95\% Credible } \\
\text { set }\end{array}$ & $\begin{array}{c}\text { Ergodic } \\
\text { mean }\end{array}$ & $\begin{array}{l}95 \% \text { Credible } \\
\text { set }\end{array}$ & $\begin{array}{c}\text { Ergodic } \\
\text { mean }\end{array}$ & $\begin{array}{c}95 \% \text { Credible } \\
\text { set }\end{array}$ \\
\hline$\alpha_{0}\left(s_{t}^{M}\right)$ & $\begin{array}{l}-0.007 \\
(0.372)\end{array}$ & {$[-0.753,0.731]$} & $\begin{array}{l}6.074 \\
(0.373)\end{array}$ & {$[5.326,6.182]$} & $\begin{array}{l}13.02 \\
(4.715)\end{array}$ & {$[3.57,22.45]$} & $\begin{array}{l}27.86 \\
(0.769)\end{array}$ & $\begin{array}{l}{[26.322} \\
29.398]\end{array}$ \\
\hline$\alpha_{\pi}\left(s_{t}^{M}\right)$ & $\begin{array}{l}-0.174 \\
(0.021)\end{array}$ & $\begin{array}{l}{[-0.218,-} \\
0.131]\end{array}$ & $\begin{array}{l}0.023 \\
(0.022)\end{array}$ & {$[-0.019,0.069]$} & $\begin{array}{l}-0.422 \\
(0.059)\end{array}$ & {$[-0.54,-0.304]$} & $\begin{array}{l}0.022 \\
(0.007)\end{array}$ & {$[0.008,0.036]$} \\
\hline$\alpha_{y}\left(s_{t}^{M}\right)$ & $\begin{array}{l}0.087 \\
(0.01)\end{array}$ & {$[0.067,0.107]$} & $\begin{array}{l}0.023 \\
(0.011)\end{array}$ & {$[0.002,0.045]$} & $\begin{array}{l}-0.086 \\
(0.093)\end{array}$ & {$[-0.272,-0.1]$} & $\begin{array}{l}-0.033 \\
(0.011)\end{array}$ & $\begin{array}{l}{[-0.055,-} \\
0.011]\end{array}$ \\
\hline$\alpha_{e x}\left(s_{t}^{M}\right)$ & $\begin{array}{l}0.517 \\
(0.051)\end{array}$ & {$[0.416,0.618]$} & $\begin{array}{l}0.298 \\
(0.051)\end{array}$ & {$[0.196,0.4]$} & $\begin{array}{l}1.675 \\
(0.411)\end{array}$ & {$[0.853,2.479]$} & $\begin{array}{l}0.848 \\
(0.627)\end{array}$ & {$[-0.406,2.102]$} \\
\hline$\alpha_{c m}\left(s_{t}^{M}\right)$ & $\begin{array}{l}0.021 \\
(0.001)\end{array}$ & {$[0.017,0.023]$} & $\begin{array}{l}-0.004 \\
(0.001)\end{array}$ & {$[-0.003,0.026]$} & $\begin{array}{l}0.019 \\
(0.012)\end{array}$ & {$[0.005,0.043]$} & $\begin{array}{l}-0.005 \\
(0.003)\end{array}$ & {$[-0.011,0.001]$} \\
\hline$\rho_{1}\left(s_{t}^{M}\right)$ & $\begin{array}{l}0.781 \\
(0.01)\end{array}$ & {$[0.761,0.801]$} & $\begin{array}{l}0.899 \\
(0.01)\end{array}$ & {$[0.879,0.919]$,} & & & & \\
\hline$\sigma\left(s_{t}^{M}\right)$ & 0.369 & & 0.014 & & 1.59 & & 0.44 & \\
\hline $\mathbb{P}_{i i}$ & 0.85 & & 0.95 & & 0.95 & & 0.97 & \\
\hline $\mathbb{P}_{i j}$ & 0.15 & & 0.05 & & 0.05 & & 0.03 & \\
\hline $\mathbb{E}(D)$ & 6.66 & & 20 & & 20 & & 33.3 & \\
\hline MixLik & -223.8 & & & & -173.97 & & & \\
\hline
\end{tabular}




\begin{tabular}{|c|c|c|c|c|c|c|c|c|}
\hline & \multicolumn{4}{|c|}{ Nigeria } & \multicolumn{4}{|c|}{ Brazil } \\
\hline & \multicolumn{2}{|c|}{ Active policy } & \multicolumn{2}{|c|}{ Passive policy } & \multicolumn{2}{|c|}{ Active policy } & \multicolumn{2}{|c|}{ Passive policy } \\
\hline & $\begin{array}{l}\text { Ergodic } \\
\text { mean }\end{array}$ & $\begin{array}{c}95 \% \text { Credible } \\
\text { set } \\
\end{array}$ & $\begin{array}{c}\text { Ergodic } \\
\text { mean }\end{array}$ & $\begin{array}{c}95 \% \text { Credible } \\
\text { set }\end{array}$ & $\begin{array}{c}\text { Ergodic } \\
\text { mean }\end{array}$ & $\begin{array}{c}95 \% \text { Credible } \\
\text { set } \\
\end{array}$ & $\begin{array}{c}\text { Ergodic } \\
\text { mean }\end{array}$ & $\begin{array}{c}95 \% \text { Credible } \\
\text { set }\end{array}$ \\
\hline$\alpha_{0}\left(s_{t}^{M}\right)$ & $\begin{array}{l}-0.015 \\
(0.001)\end{array}$ & $\begin{array}{l}-0.017,- \\
0.013]\end{array}$ & $\begin{array}{l}-0.011 \\
(0.001)\end{array}$ & $\begin{array}{l}{[-0.013,-} \\
0.009]\end{array}$ & $\begin{array}{l}1.164 \\
(0.228)\end{array}$ & {$[0.708,1.621]$} & $\begin{array}{l}-1.826 \\
(0.225)\end{array}$ & $\begin{array}{l}{[-2.276,-} \\
1.376]\end{array}$ \\
\hline$\alpha_{\pi}\left(s_{t}^{M}\right)$ & $\begin{array}{l}0.019 \\
(0.002)\end{array}$ & {$[0.015,0.024]$} & $\begin{array}{l}0.065 \\
(0.002)\end{array}$ & {$[0.061,0.071]$} & $\begin{array}{l}-0.005 \\
(0.174)\end{array}$ & {$[-0.354,0.342]$} & $\begin{array}{l}-0.077 \\
(0.173)\end{array}$ & {$[-0.27,0.425]$} \\
\hline$\alpha_{y}\left(s_{t}^{M}\right)$ & $\begin{array}{l}0.039 \\
(0.011)\end{array}$ & {$[0.019,0.059]$} & $\begin{array}{l}0.182 \\
(0.012)\end{array}$ & {$[0.162,0.203]$} & $\begin{array}{l}-0.003 \\
(0.176)\end{array}$ & {$[-0.35,0.356]$} & $\begin{array}{l}-0.016 \\
(0.169)\end{array}$ & {$[-0.356,0.323]$} \\
\hline$\alpha_{e x}\left(s_{t}^{M}\right)$ & $\begin{array}{l}0.065 \\
(0.016)\end{array}$ & {$[0.033,0.097]$} & $\begin{array}{l}0.325 \\
(0.016)\end{array}$ & {$[0.293,0.375]$} & $\begin{array}{l}0.710 \\
(0.181)\end{array}$ & {$[-0.348,1.072]$} & $\begin{array}{l}-0.005 \\
(0.174)\end{array}$ & {$[-0.354,0.343]$} \\
\hline$\rho_{1}\left(s_{t}^{M}\right)$ & $\begin{array}{l}0.898 \\
(0.004)\end{array}$ & {$[0.888,0.908]$} & $\begin{array}{l}0.921 \\
(0.004)\end{array}$ & {$[0.911,0.931]$} & $\begin{array}{l}0.231 \\
(0.077)\end{array}$ & {$[0.076,0.385]$} & $\begin{array}{l}0.825 \\
(0.077)\end{array}$ & {$[0.671,0.979]$} \\
\hline$\sigma\left(s_{t}^{M}\right)$ & 2.59 & & 0.82 & & 0.24 & & 0.12 & \\
\hline $\mathbb{P}_{i i}$ & 0.91 & & 0.92 & & 0.82 & & 0.94 & \\
\hline $\mathbb{P}_{i j}$ & 0.09 & & 0.08 & & 0.18 & & 0.06 & \\
\hline $\mathbb{E}(D)$ & 11.1 & & 12.5 & & 5.5 & & 16.6 & \\
\hline MixLik & -150.28 & & & & $-4.4 \mathrm{e}^{3}$ & & & \\
\hline
\end{tabular}




\begin{tabular}{|c|c|c|c|c|c|c|c|c|}
\hline & \multicolumn{4}{|c|}{ South Africa } & \multicolumn{4}{|c|}{ Canada } \\
\hline & \multicolumn{2}{|c|}{ Active policy } & \multicolumn{2}{|c|}{ Passive policy } & \multicolumn{2}{|c|}{ Active policy } & \multicolumn{2}{|c|}{ Passive policy } \\
\hline & $\begin{array}{l}\text { Ergodic } \\
\text { mean }\end{array}$ & $\begin{array}{c}95 \% \text { Credible } \\
\text { set }\end{array}$ & $\begin{array}{c}\text { Ergodic } \\
\text { mean }\end{array}$ & $\begin{array}{l}\text { 95\% Credible } \\
\text { set }\end{array}$ & $\begin{array}{l}\text { Ergodic } \\
\text { mean }\end{array}$ & $\begin{array}{c}95 \% \text { Credible } \\
\text { set }\end{array}$ & $\begin{array}{l}\text { Ergodic } \\
\text { mean }\end{array}$ & $\begin{array}{l}95 \% \text { Credible } \\
\text { set }\end{array}$ \\
\hline$\alpha_{0}\left(s_{t}^{M}\right)$ & $\begin{array}{l}1.677 \\
(0.151)\end{array}$ & {$[1.315,2.038]$} & $\begin{array}{l}-1.352 \\
(0.175)\end{array}$ & $\begin{array}{l}{[-1.702,-} \\
1.001]\end{array}$ & $\begin{array}{l}-1.258 \\
(0.151)\end{array}$ & $\begin{array}{l}{[-1.607,-} \\
0.909]\end{array}$ & $\begin{array}{l}1.184 \\
(0.169)\end{array}$ & {$[0.845,1.523]$} \\
\hline$\alpha_{\pi}\left(s_{t}^{M}\right)$ & $\begin{array}{l}-0.018 \\
(0.099)\end{array}$ & {$[-0.216,0.18]$} & $\begin{array}{l}0.388 \\
(0.097)\end{array}$ & {$[0.193,0.583]$} & $\begin{array}{l}-0.097 \\
(0.151)\end{array}$ & {$[-0.399,0.204]$} & $\begin{array}{l}0.051 \\
(0.151)\end{array}$ & {$[-0.246,0.349]$} \\
\hline$\alpha_{y}\left(s_{t}^{M}\right)$ & $\begin{array}{l}-0.005 \\
(0.147)\end{array}$ & {$[-0.299,0.289]$} & $\begin{array}{l}0.122 \\
(0.141)\end{array}$ & {$[-0.158,0.403]$} & $\begin{array}{l}-0.012 \\
(0.151)\end{array}$ & {$[-0.313,0.289]$} & $\begin{array}{l}-0.081 \\
(0.152)\end{array}$ & {$[-0.381,0.221]$} \\
\hline$\alpha_{e x}\left(s_{t}^{M}\right)$ & $\begin{array}{l}0.077 \\
(0.129)\end{array}$ & {$[-0.181,0.335]$} & $\begin{array}{l}0.309 \\
(0.125)\end{array}$ & {$[0.058,0.559]$} & $\begin{array}{l}0.023 \\
(0.154)\end{array}$ & {$[-0.285,0.331]$} & $\begin{array}{l}-0.001 \\
(0.152)\end{array}$ & {$[-0.306,0.303]$} \\
\hline$\alpha_{c m}\left(s_{t}^{M}\right)$ & $\begin{array}{l}0.015 \\
(0.127)\end{array}$ & {$[-0.239,0.271]$} & $\begin{array}{l}0.293 \\
(0.123)\end{array}$ & {$[0.047,0.539]$} & $\begin{array}{l}0.717 \\
(0.149)\end{array}$ & {$[0.419,1.015]$} & $\begin{array}{l}-0.086 \\
(0.151)\end{array}$ & {$[-0.387,0.213]$} \\
\hline$\rho_{1}\left(s_{t}^{M}\right)$ & $\begin{array}{l}0.956 \\
(0.061) \\
\end{array}$ & {$[0.835,1.077]$} & $\begin{array}{l}0.052 \\
(0.061) \\
\end{array}$ & {$[-0.069,0.173]$} & $\begin{array}{l}0.365 \\
(0.064) \\
\end{array}$ & {$[0.236,0.495]$} & $\begin{array}{l}0.597 \\
(0.063) \\
\end{array}$ & {$[0.471,0.725]$} \\
\hline$\sigma\left(s_{t}^{M}\right)$ & 0.05 & & 0.11 & & 0.04 & & 0.03 & \\
\hline $\mathbb{P}_{i i}$ & 0.97 & & 0.78 & & 0.85 & & 0.91 & \\
\hline $\mathbb{P}_{i j}$ & 0.03 & & 0.22 & & 0.15 & & 0.09 & \\
\hline $\mathbb{E}(D)$ & 33.3 & & 4.5 & & 6.66 & & 11.1 & \\
\hline MixLik & -328.71 & & & & 96.89 & & & \\
\hline
\end{tabular}

The ergodic means are estimates of the averages from the posterior distribution after identification using unconstrained permutation sampling of 10,000 iterations with a burn-in phase of 2,000 iterations. The $95 \%$ credible set contains the $95 \%$ highest posterior density interval (HPDI) for the estimated parameters. Standard errors are in parenthesis. $\mathbb{P}_{i i}$ is the persistence probability or the probability of remaining in the same state from periods 1 to $2 . \mathbb{P}_{i j}$ is the transition probability and $\mathbb{E}(D)$ is the expected duration of the policy rule. 
The Bayesian results for the Markov-switching fiscal policy rule are presented in Table 7. We find that the critical factor distinguishing the two regimes is the sign of the coefficient on past debt $\gamma_{b_{t-1}}$, the only exceptions are for Nigeria and Brazil (although it is possible to arrive at the same conclusion when one considers the $95 \%$ credible set of the estimates for Brazil). Following the characterization in Leeper (1991), when the fiscal authority is constrained by both consumer optimization behaviour and an active monetary policy, it must generate sufficient revenue to balance the budget. Hence, whenever the government sufficiently increases (tax) revenue in response to the past level of government debt, i.e., $\gamma_{b_{t-1}}>0$, fiscal policy is described as being passive. ${ }^{10}$ On the other hand, when the fiscal authority is not constrained by the current budgetary conditions, it follows an active policy regime that responds negatively to debt. The active policy regime is more consistent with the predictions of business cycle theory, where fluctuations in revenue and debt are expected to covary negatively (see Davig and Leeper, 2006).

Surprisingly, with the exception of South Africa, the response of fiscal authorities to the output gap does not change across regimes for nearly all the countries under investigation. This is in contrast to the sign switching estimates for the US by Favero and Monacelli (2005), but similar to the fixed sign results for the US by Davig and Leeper (2006) and the mixed results for EU countries by Gali and Perotti (2003). Therefore, we conclude that for the type of economies under investigation, the response of fiscal policy to the output gap has been consistent in spite of the policy regime.

Furthermore, the results in Table 7 indicate that fiscal policy has been procyclical in Brazil, Chile, Nigeria, and South-Africa but counter-cyclical in Canada. The extent of pro-cyclicality depends on the fiscal regime in place, with the effect being more pronounced mostly during the passive fiscal regimes in most of the countries. These results are generally consistent with the theoretical and empirical literature, which show that developing countries experience larger cyclical fluctuations than their industrialized counterparts in response to commodity price booms. Among other factors, one main reason for this observation is that the economic and institutional structures that are designed to check these problems are generally weaker in the former (see Frankel et al., 2013; Kaminsky et al., 2005; Talvi and Vegh, 2005, for examples)

\footnotetext{
${ }^{10}$ Note that in an optimization-based framework, it is further required that the response of tax policy to debt be greater than the quarterly real interest rate (see Chung et al., 2007; Davig and Leeper, 2006; Leeper, 1991).
} 
Figure 3: Filtered and smoothed transition probabilities for active fiscal policy.
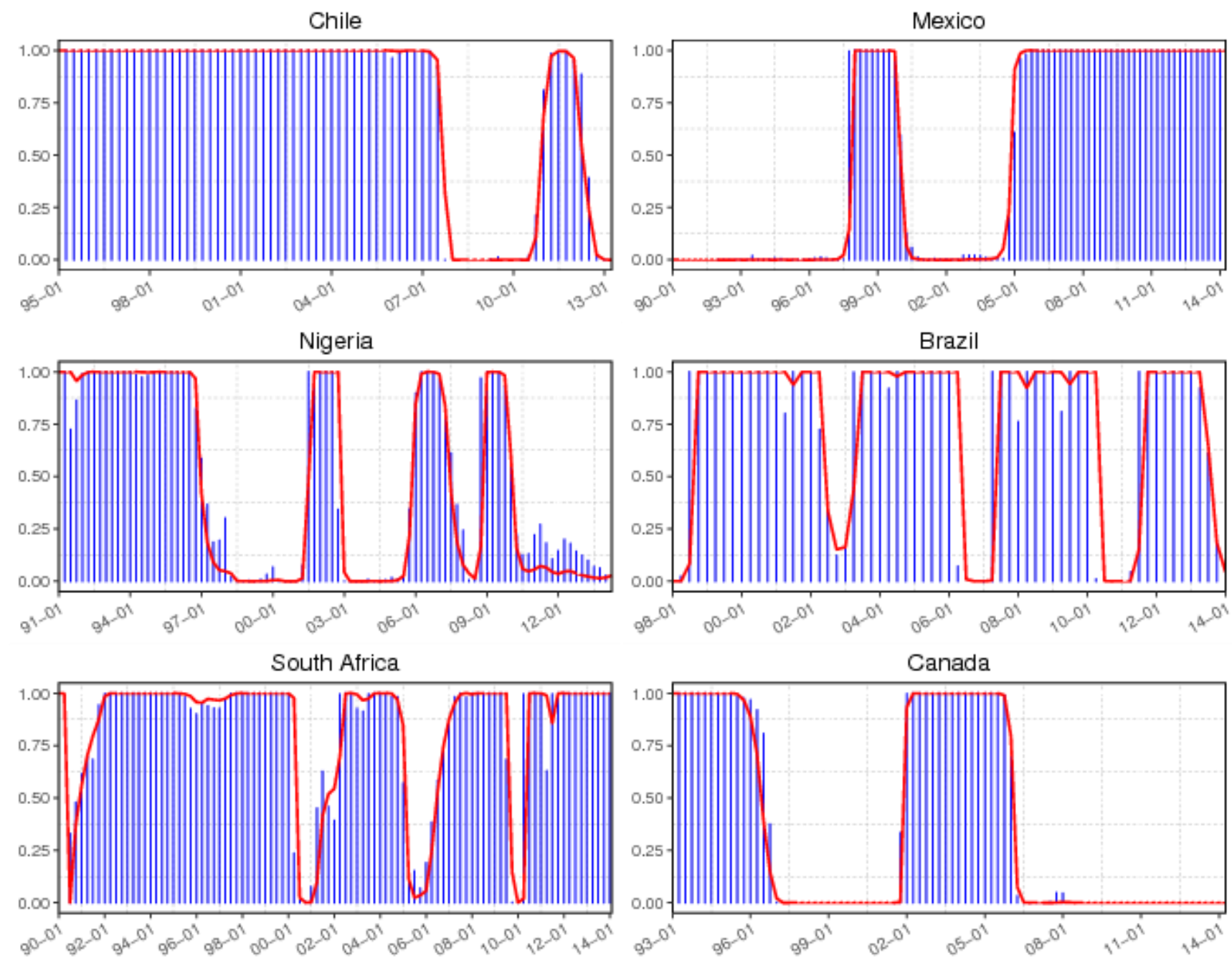

Figure 3 displays the filtered (plotted as bars) and smoothed (plotted as lines) transition probabilities of the active fiscal policy regime. The degree of persistence in the policy regimes is discernible from the respective stationary transition probabilities. The results clearly indicate that the policy regimes are persistent. The expected duration of the active fiscal policy regime $\mathbb{E}(D)$ ranges between 33 quarters in South Africa and 6 quarters in Brazil. Further, we observe that the fiscal policy episodes in Canada are clearly distinct. Between 2001 and 2006, fiscal policy was mostly active, and since the financial crisis in 2007 until 2014, fiscal policy has been passive in Canada. Note, that the chart in Figure 3 shows the transition probabilities for the policy reaction functions, so in this case we are unable to match these probbilities with episodes in respective business cycle episodes. 
Figure 4: Identified equilibrium outcome from joint policy interactions
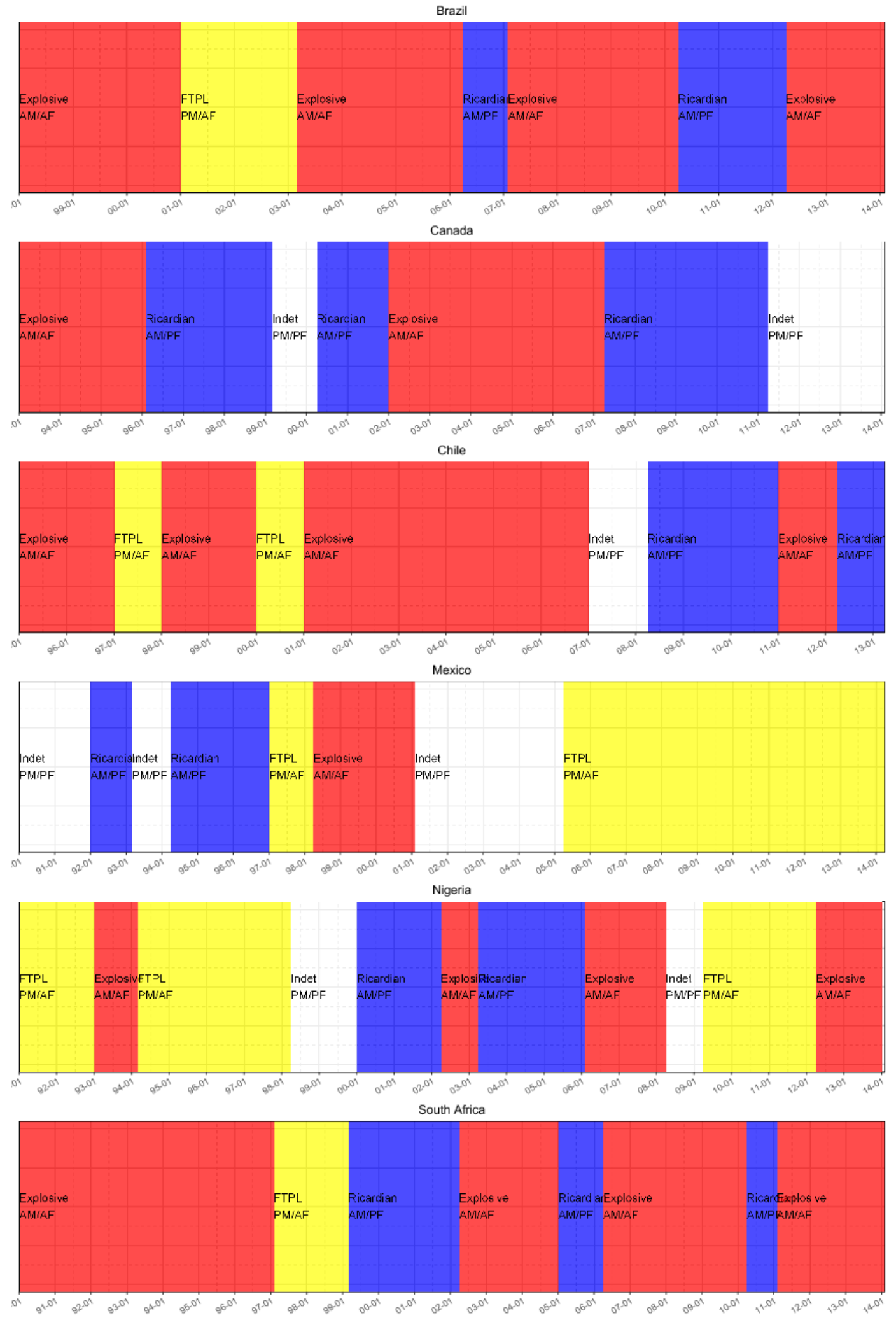

Note: Identified equilibria interaction outcomes between monetary and fiscal policy based on the Kronecker multiplication of the transition probabilities matrices. 


\subsection{Policy interactions}

The equilibrium outcome of the interactions between monetary and fiscal policy regimes for each country is obtained from the joint transition probability matrix, which is a Kronecker multiplication of the individual transition probabilities, $\mathcal{P}=\mathbb{P}^{M} \otimes \mathbb{P}^{F}$. The dynamic equilibrium outcomes of the interaction between monetary and fiscal policy regimes are plotted in Figure 4. The joint policy framework is "explosive" whenever both monetary and fiscal policy regimes are active (the red segment in Figure 4); it is "Ricardian" when active monetary policy interacts with passive fiscal policy (the blue segment); it is the fiscal theory of the price level (FTPL) when passive monetary policy interacts with active fiscal policy (the yellow segment); and lastly, it is "indeterminate" when both monetary and fiscal policies are passive (the white segment).

Figure 4 indicates that for Mexico and Nigeria, it is the fiscal theory of the price level that has dominated the historical narrative; that is, fiscal policy has mostly been active while monetary policy has been accommodating. In Chile, Brazil and South Africa, the dominant outcome of policy interaction is mostly 'active-active' and hence explosive policy, where the monetary and fiscal authorities are simultaneously active (without coordination) in controlling the price level. The experience in Canada is quite different from the rest, as the outcome of the policy mix tends to indicate mostly Ricardian episodes, followed by sustained periods of policy explosiveness.

\section{Conclusion}

In this study, we have investigated the importance of commodity price fluctuations for monetary and fiscal policy formulation in countries that display a high dependency on primary commodities in total merchandise exports. Furthermore, we have taken the opportunity to study the interactions between monetary and fiscal policy rules based on the identified policy episodes in the selected countries. To achieve this, we have estimated modified versions of the standard Taylor-type monetary policy rule, and Leeper type fiscal policy rule, stylized to account for commodity price slacks.

The key results of the study are that both monetary and fiscal authorities in high-resource export economies respond to commodity price slacks, albeit in different ways depending on the policy regime in place; secondly, that monetary and fiscal policy are characterized by distinctive episodes of active and passive policy regimes; thirdly that monetary authorities in these economies 
often fail to act aggressively enough to achieve their announced inflation targets; and finally that there is little to no evidence of policy synchronization between monetary and fiscal policy in these economy types.

Some policy implications emerge from our results. The policy interactions for most of the economies provide evidence that the fiscal theory of the price level has been in operation, so that the path of government debt has driven the price level for these economies. This implies a need or emphasis towards economic stability and that macroeconomic management for these economies should rest more with fiscal authorities than it does with monetary authorities. There is also evidence of a lack of synchronization and policy coordination between policymakers for all of the economies concerned, suggesting that better communication of policy rules in operation might help to improve macro outcomes.

Finally, it is worth highlighting that the findings presented here rely on the estimation of simple monetary and fiscal rules, and consequently, we are unable to extend this under an optimal rule framework. Nevertheless, the consistent results we obtain on the relevance of commodity price slacks and the regime switching nature of the estimated policy rules hold interesting implications for the correct specification of the monetary-fiscal policy mix in modern workhorse New-Keynesian models, used for policy analysis in economies that are characterized by significant export shares of primary commodities. 
Appendix

Table A1. Variable Description and Sources

\begin{tabular}{|c|c|c|}
\hline Variable & Description & Sources \\
\hline Inflation & $\begin{array}{l}\text { The growth rate of the consumer } \\
\text { price index }\end{array}$ & $\begin{array}{l}\text { International Financial Statistics } \\
\text { (IFS), International Monetary Fund } \\
\text { (IMF) and augmented with data } \\
\text { from relevant national statistical } \\
\text { bodies. }\end{array}$ \\
\hline Exchange rate & $\begin{array}{l}\text { Domestic currency per U.S dollar at } \\
\text { the end of each period. }\end{array}$ & $\begin{array}{l}\text { International Financial Statistics } \\
\text { (IFS), International Monetary Fund } \\
\text { (IMF) and augmented with data } \\
\text { from relevant national statistical } \\
\text { bodies. }\end{array}$ \\
\hline Monetary policy rate & $\begin{array}{l}\text { Monetary policy-related interest } \\
\text { rate, in percent }\end{array}$ & $\begin{array}{l}\text { International Financial Statistics } \\
\text { (IFS), International Monetary Fund } \\
\text { (IMF) and augmented with data } \\
\text { from relevant national statistical } \\
\text { bodies. }\end{array}$ \\
\hline $\begin{array}{l}\text { Country-specific } \\
\text { relevant commodity } \\
\text { price slack }\end{array}$ & $\begin{array}{l}\text { The price index of the major } \\
\text { commodities traded by each } \\
\text { country: for Brazil--iron ore and } \\
\text { petroleum; for Chile-- copper ore, } \\
\text { refined and raw copper; for Canada- } \\
\text {-crude petroleum, and refined } \\
\text { petroleum; for Mexico--crude } \\
\text { petroleum; for Nigeria--crude } \\
\text { petroleum and petroleum gas; and } \\
\text { for South Africa--gold, diamonds } \\
\text { and platinum. }\end{array}$ & $\begin{array}{l}\text { Commodity price database of the } \\
\text { International Monetary Fund. }\end{array}$ \\
\hline $\begin{array}{l}\text { Public debt-to-GDP } \\
\text { ratio }\end{array}$ & $\begin{array}{l}\text { Public debt-to-GDP ratio based on } \\
\text { comprehensive } \\
\text { calculations by Reinhart and Rogoff }\end{array}$ & Reinhart and Rogoff (2011) \\
\hline $\begin{array}{l}\text { Government } \\
\text { Spending-to-GDP } \\
\text { ratio }\end{array}$ & $\begin{array}{l}\text { Total government expenditure-to- } \\
\text { GDP, including interest payments } \\
\text { and subsidies }\end{array}$ & $\begin{array}{lll}\text { World } & \text { Development } & \text { Indicators } \\
\text { (WDI) } & & \end{array}$ \\
\hline
\end{tabular}




\begin{tabular}{|l|l|lr|}
\hline $\begin{array}{l}\text { Revenue-to-GDP } \\
\text { ratio }\end{array}$ & $\begin{array}{l}\text { Ratio of revenue from taxes, social } \\
\text { contribution and other revenues to } \\
\text { GDP }\end{array}$ & $\begin{array}{l}\text { World Development Indicators } \\
\text { (WDI) }\end{array}$ \\
\hline Output gap & $\begin{array}{l}\text { This is calculated as the HP-filtered } \\
\text { divergence between actual real GDP } \\
\text { and its trend value in percentage } \\
\text { terms, scaled by 100. }\end{array}$ & $\begin{array}{l}\text { International Financial Statistics } \\
\text { (IFS), International Monetary Fund } \\
\text { (IMF). }\end{array}$ \\
\hline
\end{tabular}

\section{References}

Assenmacher-Wesche, K., 2006. Estimating central banks preferences from a time-varying empirical reaction function. European Economic Review 50 (8), 1951-1974.

Belke, A. H., Bordon, I. G., Hendricks, T. W., 2014. Monetary policy, global liquidity and commodity price dynamics. The North American Journal of Economics and Finance 28, 1 - 16.

Bernanke, B., 2017. Monetary policy in a new era. Peterson institute.

Bernanke, B., Gertler, M., 1999. Monetary policy and asset price volatility. Economic Review: Federal Reserve Bank of Kansas City (4), 17-51.

Bernanke, B., Gertler, M., 2001. Should central banks respond to movements in asset prices? American Economic Review, 253-257.

Bjrnland, H. C., Halvorsen, J. I., 2014. How does monetary policy respond to exchange rate movements? new international evidence. Oxford Bulletin of Economics and Statistics 76 (2), 208-232.

Bohn, H., 1998. The behavior of US public debt and deficits. Quarterly Journal of Economics, 949-963.

Caballero, R. J., Farhi, E., Gourinchas, P. O., 2008. Financial crash, commodity prices, and global imbalances. Brookings Papers on Economic Activity, Fall, 1-55.

Cecchetti, S. G., Genberg, H., Lipsky, J., Wadhwani, S. B., 2000. Asset prices and central bank policy. Geneva Reports on the World Economy 2 1, 1-152.

Cevik, E. I., Dibooglu, S., Kutan, A. M., 2014. Monetary and fiscal policy interactions: Evidence from emerging European economies. Journal of Comparative Economics 42 (4), 1079-1091. 
Chung, H., Davig, T., Leeper, E. M., 2007. Monetary and fiscal policy switching. Journal of Money, Credit and Banking 39 (4), 809-842.

Clarida, R., Gall, J., Gertler, M., 1998. Monetary policy rules in practice: some international evidence. European Economic Review 42 (6), 1033-1067.

Corbo, V., Landerretche, O., Schmidt-Hebbel, K., 2002. Does inflation targeting make a difference? In: Loayza, N., Soto, R. (Eds.), Inflation Targeting: Design, Performance, Challenges. Santiago, Chile, Central Bank of Chile, pp. 221-69.

Davig, T., Leeper, E. M., 2006. Fluctuating macro policies and the fiscal theory. In: Acemoglu, D., Rogoff, F., Woodford, M. (Eds.), NBER Macroeconomics Annual 2006, Volume 21. MIT Press, Cambridge, pp. 247-316.

Davig, T., Leeper, E. M., 2011. Monetary-fiscal policy interactions and fiscal stimulus. European Economic Review 55 (2), 211-227.

Dempster, A. P., Laird, N. M. and Rubin, D. B. 1977. Maximum likelihood from incomplete data via the EM algorithm, Journal of the Royal Statistical Society pp. 1-38.

Favero, C. and Monacelli, T. 2005. Fiscal Policy Rules and Regime (In) Stability: Evidence from the US, Technical Report, IGIER (Innocenzo Gasparini Institute for Economic Research), Bocconi University.

Favero, C., Rovelli, R., 2003. Macroeconomic stability and the preferences of the Fed: A formal analysis, 1961-98. Journal of Money, Credit, and Banking 35 (4), 545-556.

Frankel, J. 2011. How can commodity exporters make fiscal and monetary policy less procyclical?, in T. Arezki, R. Gylfason and A. Sy (eds), Beyond the Curse: Policies to Harness the Power of Natural Resources, International Monetary Fund, chapter 10, pp. 167-201.

Frankel, J., Vegh, C. A. and Vuletin, G. 2013. On graduation from fiscal procyclicality, Journal of Development Economics 100(1): 32-47.

Fruhwirth-Schnatter, S. 2004. Estimating marginal likelihoods for mixture and Markov switching models using bridge sampling techniques, The Econometrics Journal 7(1): 143-167.

Fruhwirth-Schnatter, S. 2006. Finite mixture and Markov switching models, Springer Science \& Business Media.

Gali, J. and Perotti, R. 2003. Fiscal policy and monetary integration in Europe, Economic Policy 18(37): 533-572.

Goodfriend, M., 1991. Interest rates and the conduct of monetary policy. In: Carnegie-Rochester 
Conference Series on Public Policy. Vol. 34. Elsevier, pp. 7-30.

Hadri, K., 2011. Primary commodity price series: Lessons for policy makers in resource-rich economies. In: Arezki, R. Gylfason, T., Sy, A. (Eds.), Beyond the Curse: Policies to Harness the Power of Natural Resources. International Monetary Fund, Ch. 7, pp. 119-130.

Harvey, D. I., Kellard, N. M., Madsen, J. B., Wohar, M. E., 2010. The Prebisch-singer hypothesis: four centuries of evidence. The Review of Economics and Statistics 92 (2), 367-377.

Hegerty, S. W., 2016. Commodity-price volatility and macroeconomic spillovers: Evidence from nine emerging markets. The North American Journal of Economics and Finance 35, 23-37.

Kaminsky, G. L., Reinhart, C. M. and Vegh, C. A. 2005. When it rains, it pours: Procyclical capital flows and macroeconomic policies, NBER Macroeconomics Annual pp. 11-53

Kaufmann, S. (2002). Is there an asymmetric effect of monetary policy over time? A Bayesian analysis using Austrian data., Empirical Economics 27(2): 277-297.

Karlis, D. and Xekalaki, E. (2003). Choosing initial values for the EM algorithm for finite mixtures, Computational Statistics \& Data Analysis 41(3): 577-590.

Kim, C.-J., Nelson, C. R., 1999a. Has the US economy become more stable? A Bayesian approach based on a Markov-switching model of the business cycle. Review of Economics and Statistics $81(4), 608-616$.

Kim, C.-J., Nelson, C. R., 1999b. State-space models with regime switching: classical and Gibbssampling approaches with applications. Vol. 1. The MIT Press.

Leeper, E. M., 1991. Equilibria under active and passive monetary and fiscal policies. Journal of Monetary Economics 27 (1), 129-147.

Liu, Z., Waggoner, D. F., Zha, T., 2011. Sources of macroeconomic fluctuations: A regimeswitching DSGE approach. Quantitative Economics 2 (2), 251-301.

Lubik, T. A., Schorfheide, F., 2007. Do central banks respond to exchange rate movements? a structural investigation. Journal of Monetary Economics 54 (4), 1069-1087.

Mohanty, M. S., Klau, M., 2005. Monetary policy rules in emerging market economies: Issues and evidence. In: Langhammer, R. J., de Souza, L. V. (Eds.), Monetary Policy and Macroeconomic Stabilization in Latin America. Springer, pp. 205-251.

Muscatelli, V. A., Tirelli, P., Trecoci, C., 2002. Does institutional change really matter? Inflation targets, central bank reform and interest rate policy in the OECD countries. The Manchester School 70 (4), 487-527. 
Owyang, M. T. and Ramey, G. 2004. Regime switching and monetary policy measurement, Journal of Monetary Economics 51(8): 1571-1597.

Prebisch, R., 1950. The economic development of Latin America and its principal problems. United Nations, New York.

Reinhart, C. M., Rogoff, K. S., 2009. This time is different: Eight centuries of financial folly. Princeton University Press.

Sidaoui, J., 2003, October. Implications of fiscal issues for central banks: Mexico's experience. BIS Working Paper No. 20.

Siklos, P. L., 2008. Inflation targeting around the world. Emerging Markets Finance and Trade 44 (6), 17-37.

Siklos, P. L., Bohl, M. T., 2009. Asset prices as indicators of Euro area monetary policy: an empirical assessment of their role in a Taylor rule. Open Economies Review 20 (1), 39-59.

Sims, C. A. (1999). Drift and breaks in monetary policy, Manuscript, Princeton University

Singer, H. W., 1950. The distribution of gains between investing and borrowing countries. The American Economic Review 40 (2), 473-485.

Svensson, L. E., 2000. Open-economy inflation targeting. Journal of International Economics 50 (1), 155-183.

Talvi, E. and Vegh, C. A. 2005. Tax base variability and procyclical fiscal policy in developing countries, Journal of Development Economics 78(1): 156-190.

Taylor, J. B., 1993. Discretion versus policy rules in practice. In: Carnegie-Rochester Conference Series on Public Policy. Vol. 39. Elsevier, pp. 195-214.

Taylor, J. B., Williams, J. C., 2010. Simple and robust rules for monetary policy. In: Handbook of Monetary Economics. Vol. 3. pp. 829-859.

Valente, G., 2003. Monetary policy rules and regime shifts. Applied Financial Economics 13 (7), $525-535$.

Winkelried, D., 2016. Piecewise linear trends and cycles in primary commodity prices. Journal of International Money and Finance 64, 196-213.

Woodford, M., 1995. Price-level determinacy without control of a monetary aggregate. In: Carnegie- Rochester Conference Series on Public Policy. Vol. 43. Elsevier, pp. 1-46. 
Woodford, M., 2001. Fiscal requirements for price stability. Journal of Money, Credit and Banking, 669-728.

Woodford, M., 2002. Inflation stabilization and welfare. NBER Contributions in Macroeconomics 2 (1), 1534-6005.

Yamada, H., Yoon, G., 2014. When Grilli and Yang meet Prebisch and Singer: Piecewise linear trends in primary commodity prices. Journal of International Money and Finance 42, 193-207. 